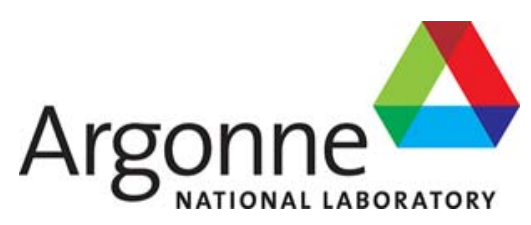

\title{
Irradiation Experiment Conceptual Design Parameters for MITR LEU U-Mo Fuel Conversion
}

Nuclear Engineering Division 


\begin{abstract}
About Argonne National Laboratory
Argonne is a U.S. Department of Energy laboratory managed by UChicago Argonne, LLC under contract DE-AC02-06CH11357. The Laboratory's main facility is outside Chicago, at 9700 South Cass Avenue, Argonne, Illinois 60439. For information about Argonne and its pioneering science and technology programs, see www.anl.gov.
\end{abstract}

\title{
Availability of This Report
}

This report is available, at no cost, at http://www.osti.gov/bridge. It is also available on paper to the U.S. Department of Energy and its contractors, for a processing fee, from:

U.S. Department of Energy

Office of Scientific and Technical Information

P.O. Box 62

Oak Ridge, TN 37831-0062

phone (865) 576-8401

fax (865) 576-5728

reports@adonis.osti.gov

\section{Disclaimer}

This report was prepared as an account of work sponsored by an agency of the United States Government. Neither the United States Government nor any agency thereof, nor UChicago Argonne, LLC, nor any of their employees or officers, makes any warranty, express or implied, or assumes any legal liability or responsibility for the accuracy, completeness, or usefulness of any information, apparatus, product, or process disclosed, or represents that its use would not infringe privately owned rights. Reference herein to any specific commercial product, process, or service by trade name, trademark, manufacturer, or otherwise, does not necessarily constitute or imply its endorsement, recommendation, or favoring by the United States Government or any agency thereof. The views and opinions of document authors expressed herein do not necessarily state or reflect those of the United States Government or any agency thereof, Argonne National Laboratory, or UChicago Argonne, LLC. 


\section{Irradiation Experiment Conceptual Design Parameters for MITR LEU U-Mo Fuel Conversion}

prepared by

Erik H. Wilson ${ }^{1}$, Thomas H. Newton, Jr. ${ }^{2}$, Lin-wen $\mathrm{Hu}^{2}$, and Floyd E. Dunn ${ }^{1}$

${ }^{1}$ Nuclear Engineering Division, Argonne National Laboratory

${ }^{2}$ MIT Nuclear Reactor Laboratory

June 2013

This work is sponsored by the U.S. Department of Energy,

National Nuclear Security Administration Office of Global Threat Reduction (NA-21) 
ANL/GTRI/TM-13/6

(This page intentionally left blank) 


\begin{abstract}
This report contains the results of reactor design and performance calculations for conversion of the Massachusetts Institute of Technology Reactor (MITR) from the use of highly-enriched uranium (HEU) fuel to the use of low-enriched uranium (LEU) fuel. The analyses were performed by staff members of the Global Threat Reduction Initiative (GTRI) Reactor Conversion Program at the Argonne National Laboratory (ANL) and the MITR Facility. The core conversion to LEU is being performed with financial support from the U. S. government.

In the framework of its non-proliferation policies, the international community presently aims to minimize the amount of nuclear material available that could be used for nuclear weapons. In this geopolitical context most research and test reactors, both domestic and international, have started a program of conversion to the use of LEU fuel. A new type of LEU fuel based on an alloy of uranium and molybdenum (U-Mo) is expected to allow the conversion of U.S. domestic high performance reactors like MITR. This report presents the nominal steady-state irradiation conditions of plates containing peak irradiation parameters found in MITR cores fueled with the LEU monolithic U-Mo alloy fuel with 10 $\mathrm{wt} \%$ Mo. Manufacturing tolerances and other uncertainties in reactor geometry and materials are also presented and used to estimate the uncertainties in these irradiation parameters above nominal steadystate conditions.
\end{abstract}


ANL/GTRI/TM-13/6

(This page intentionally left blank) 


\section{TABLE OF CONTENTS}

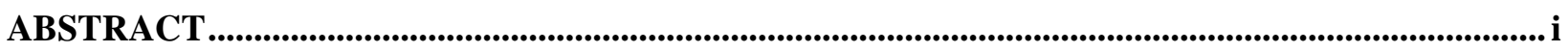

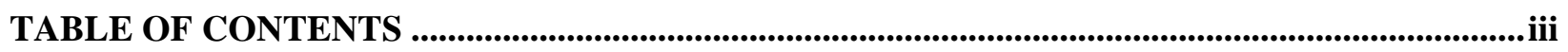

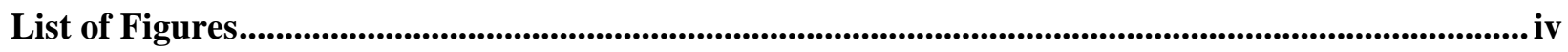

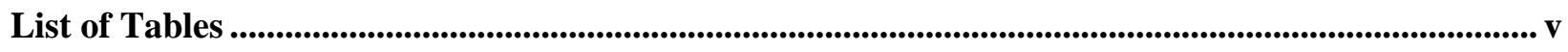

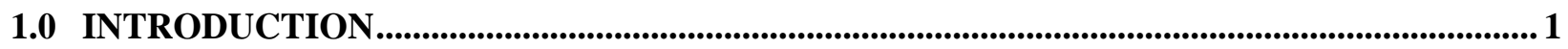

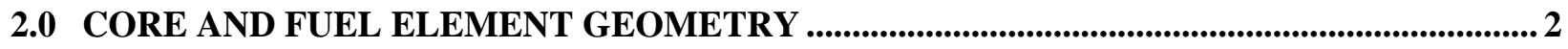

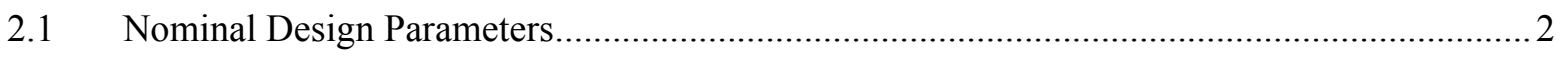

2.2 Element Design Parameters and Tolerances .................................................................. 7

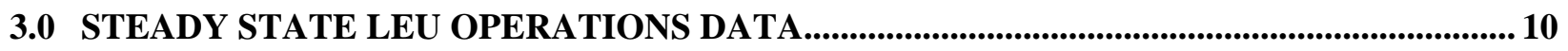

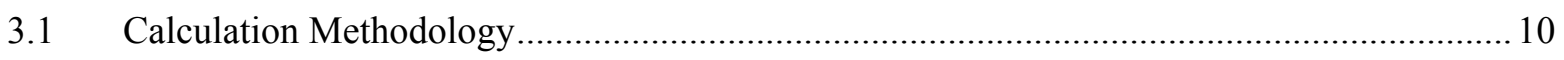

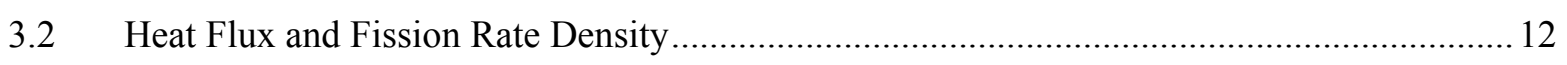

3.2.1 Power Ramping during Fuel Lifetime .......................................................................... 17

3.2.2 Fuel Plate Lateral Power Peaking................................................................................. 19

3.3 Fuel Burnup and Fission Density ……........................................................................ 22

3.4 Maximum Steady-State Temperatures for LEU Fuel ...................................................... 24

4.0 LEU IRRADIATION PARAMETERS WITH UNCERTAINTIES ....................................... 25

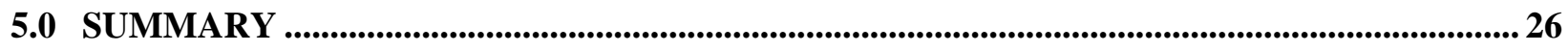

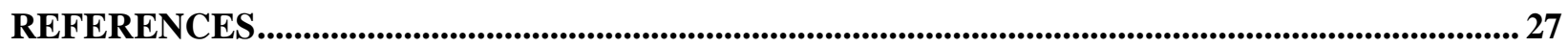




\section{$\underline{\text { List of Figures }}$}

Figure 2.1. Layout of the MIT reactor core ...................................................................................... 2

Figure 2.2. Schematic of MITR LEU fuel element drawn with 18 plates. ............................................... 4

Figure 2.3. Schematic of MITR LEU fuel element (outer 4 of 18 plates shown). ..................................... 5

Figure 2.4. HEU fuel element MITR specification R3F-201-4............................................................. 6

Figure 3.1. Axial heat flux profile of location (Core 189 BOC) and stripe (Core 189 EOC) of maximum

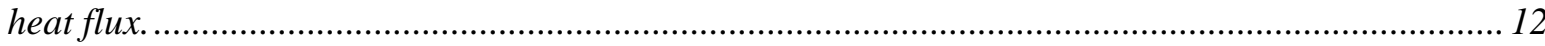

Figure 3.2. Axial heat flux profile of LEU plate with location of maximum heat flux............................. 13

Figure 3.3. Axial heat flux profile of LEU plate with stripe of maximum heat flux................................. 13

Figure 3.4. Axial heat flux $\left(q^{\prime \prime}\right)$ distribution for element of highest power:............................................. 18

Figure 3.5. Maximum local power distribution shown with detailed divisions along the plate fuel width,

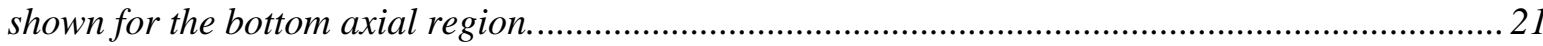

Figure 3.6. Average and peak stripe axial burnup profile for plate with highest fission density..............22

Figure 3.7. Plate average and peak stripe axial burnup profile for plate with second highest fission

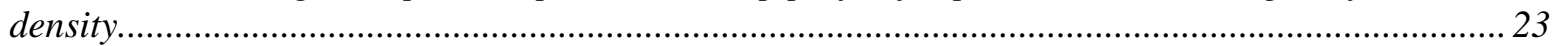

Figure 3.8. Axial temperature profile of peak stripe. .......................................................................... 24 


\section{$\underline{\text { List of Tables }}$}

Table 2.1. HEU and LEU element dimensions.

Table 2.2. Tolerance summary of HEU and LEU fuel plate and full-channel (interior channel)

dimensions.

Table 2.3. Tolerance summary of HEU and LEU end channel (outside channel) dimensions...................8

Table 2.4. Summary of element design parameters and tolerances.

Table 3.1. Discretization of the LEU depletion zones and power regions used to generate neutronic power shapes in the peak plates. ..................................................................................................... 11

Table 3.2. Axial heat flux distributions of 7 MW LEU cores with locations of maximum power.............. 14

Table 3.3. Axial heat flux distributions of 7 MW LEU cores in plate with locations of maximum power. 15

Table 3.4. Extrema and peaking in plate of 7 MW LEU cores with locations of maximum power. .......... 15

Table 3.5. Axial burnup distribution of LEU cores with maximum heat flux locations.

Table 3.6. Peak power plate when inserted as a fresh element and later in life at time of highest power.17 Table 3.7. Axial power distribution of element MIT-335 plate 1 when loaded into interior fuel ring position B1 during LEU Core 179.

Table 3.8. Detailed lateral axial heat flux distribution in plate with maximum power location. ..............220

Table 3.9. Effect of lateral division of heat flux distribution in plate with maximum power location....... 21

Table 3.10. Maximum ${ }^{235}$ U burnup in LEU Fuel Plates. ................................................................... 23

Table 4.1. Maximum parameters and uncertainties assumed for LEU fuel irradiation experiments........25 
ANL/GTRI/TM-13/6

(This page intentionally left blank) 


\subsection{INTRODUCTION}

The Massachusetts Institute of Technology is working in conjunction with the Global Threat Reduction Initiative (GTRI) Reactor Conversion Program at Argonne National Laboratory (ANL) to perform fuel element design and fuel cycle and safety analyses [1-7], and steady-state thermal-hydraulic safety analyses [8-10] to support conversion of the Massachusetts Institute of Technology Reactor (MITR) from highly-enriched uranium (HEU) to low-enriched uranium (LEU) fuel. The conversion objectives are to develop a fuel element design that will ensure safe reactor operations, acceptable shutdown and safety margins, as well as maintain the existing experimental performance of the facility.

The proposed MITR core is fueled with a monolithic alloy of uranium and $10 \mathrm{wt} \%$ molybdenum (U10Mo) with a very high density of $17.02 \mathrm{~g} / \mathrm{cm}^{3}$. The overall design and exterior dimensions are similar to those of the current HEU fuel elements, and the interior of the element has been re-designed with 18 plates of in order to meet constraints on reactivity and thermal hydraulic margins. The overall thickness of each LEU plate is 60 mil including 10 mil fins on each side of the plate. Heat transfer area is enhanced in both the HEU and LEU designs with 220 grooves that run the 23 inch length of the fuel plate to form the fins.

The LEU U10Mo monolithic fuel is not yet a qualified fuel for research reactors, but is under active development by the Fuel Fabrication Capability (FFC), Fuel Development (FD) and Reactor Conversion (RC) pillars of the National Nuclear Security Administration GTRI program to convert the U.S. High Performance Research Reactors to LEU fuel in order to minimize the amount of nuclear material available that could be used for nuclear weapons. To assist in the design of mini- and full-size plates for the irradiation experiments, as well as the planning and execution of the experimental campaign, calculated irradiation parameters have been compiled for the proposed MITR LEU design and are presented in this report.

A representative history of HEU and LEU core states that could exist during steady-state operations of the MITR were examined in $[2,4,11]$. In this report, irradiation parameters are presented for the LEU elements under the conditions that are expected in steady-state operations to represent the highest plate heat flux, fuel and clad temperatures, fission rate density, and cumulative fission density. These analyses were performed with the feasibility design, and are based on spatial nodalization of interest for safety analyses. Where relevant these may also serve as the reference for key parameters to be used in the conceptual design of the irradiation experiments. These parameters are dependent on the element design, and so if the MITR feasibility design is revised, fuel cycle irradiation parameters would require revision for incorporation into subsequent stages of the test reactor irradiation design. 


\subsection{CORE AND FUEL ELEMENT GEOMETRY}

\subsection{Nominal Design Parameters}

The MIT Reactor (MITR-II) core has a hexagonal design that contains twenty-seven fuel positions in three radial rings (A, B, and C), as shown in Figure 2.1. Typically three of these positions (two in the Aring and one in the B-ring) are filled with either an in-core experimental facility or a solid aluminum dummy element to reduce power peaking and bypass flow. The remaining positions are filled with standard MITR-II fuel elements.

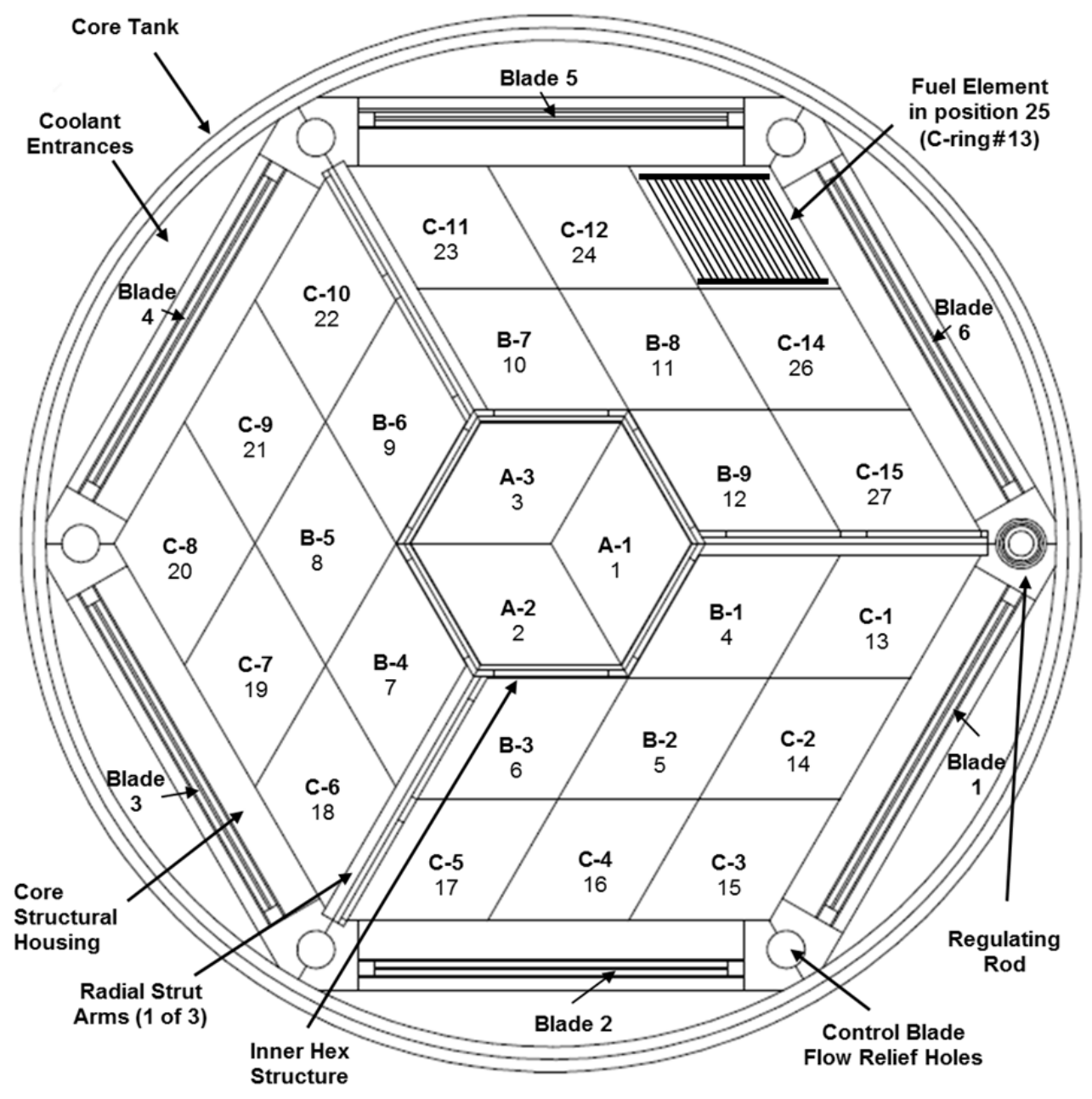

Figure 2.1. Layout of the MIT reactor core. 
The feasibility LEU design was discussed in [8]. Each rhomboid-shaped LEU fuel element contains eighteen aluminum-clad fuel plates with a fuel zone thickness of $0.508 \mathrm{~mm}(0.020 \mathrm{inch})$ and fuel zone length of $56.8325 \mathrm{~cm}(22.375 \mathrm{inch})$. The LEU fuel modeled is a uranium-molybdenum monolithic alloy enriched up to $19.75 \%{ }^{235} \mathrm{U}$, and with $10 \mathrm{wt} \%$ Mo at an overall fuel density of $17.02 \mathrm{~g} / \mathrm{cm}^{3}$. The cladding, (consisting of 6061 aluminum alloy and a thin (nominally 1 mil) zirconium layer at the fuel interface) of each fuel plate is $0.254 \mathrm{~mm}(0.010 \mathrm{inch})$ thick. In order to increase heat transfer to the coolant, there are $0.254 \mathrm{~mm}(0.010 \mathrm{inch})$ longitudinal fins in addition to the $0.254 \mathrm{~mm}(0.010 \mathrm{inch})$ cladding ( $\mathrm{Zr}$ interlayer and 6061 aluminum). The thickness of the fuel plate is $1.524 \mathrm{~mm}(0.060 \mathrm{inch})$ from fin-tip to fin-tip.

The gaps between fuel plates which form the coolant channels within an element are referred to as interior channels. These interior channels are 0.072 inch from fin-tip to fin-tip. End channels are present on the outside of the outer fuel plates. Table 2.1 lists dimensions of the LEU element, as illustrated schematically (not to scale) in Figures 2.2-2.3. The LEU element design, other than as noted, is based upon the MITR HEU fuel element drawing specification shown in Figure 2.4 [12]. Note that the unit "mil" represents 0.001 inches or 0.0254 millimeters.

Table 2.1. HEU and LEU element dimensions.

\begin{tabular}{|c|c|c|c|}
\hline & $\begin{array}{l}\text { Plate and Channel Dimensions } \\
\text { (Schematic Labels Figs. 2-3) }\end{array}$ & HEU & LEU \\
\hline & Fuel plate length (inch) & 23 & 23 \\
\hline & Fuel meat length (inch) & 22.375 & 22.375 \\
\hline & Fuel plates per assembly & 15 & 18 \\
\hline & Interior (full) channels per assembly & 14 & 17 \\
\hline & End (partial) channels per assembly & 2 & 2 \\
\hline (a) & Fuel meat thickness (mil) & 30 & 20 \\
\hline (b) & Fuel meat width (inch & 2.082 & 2.082 \\
\hline (c) & $\begin{array}{l}\text { Clad thickness } \\
\text { (base of fin to fuel surface) }\end{array}$ & $\begin{array}{c}15 \\
(6061 \mathrm{Al})\end{array}$ & $\begin{array}{c}10 \\
(6061 \mathrm{Al}+\mathrm{Zr})\end{array}$ \\
\hline (d) & Plate to plate pitch, CL to CL (mil) & 158 & 132 \\
\hline (e) & Interior channel water gap (fin tip-to-tip) (mil) & 78 & 72 \\
\hline (f) & Effective interior channel thickness (mil) & 88 & 82 \\
\hline (g) & Finned width (inch) & 2.2 & 2.2 \\
\hline & Number of fins per plate & 110 per side & 110 per side \\
\hline (h) & Fin depth (mil) & 10 & 10 \\
\hline (i) & Fin width (mil) & 10 & 10 \\
\hline (j) & Width between fuel meat and side plate (mil) & 113 & 113 \\
\hline (k) & Width between fins and side plate (mil) & 54 & 54 \\
\hline (l) & Channel width (inch) & 2.308 & 2.308 \\
\hline (m) & Side plate thickness (mil) & 188 & 188 \\
\hline (n) & $\begin{array}{l}\text { Side plate flat-to-flat, outer edge of one side plate to outer } \\
\text { edge of second side plate on element (inch) }\end{array}$ & 2.375 & 2.375 \\
\hline (o) & Element end flat-to-flat (inch) & 2.380 & 2.380 \\
\hline (p) & Outer plate fin-tip to side plate end plane (mil) & 44 & 38 \\
\hline (q) & Effective outer plate gap to side plate end plane (mil) & 49 & 43 \\
\hline & Outer plate fin-tip to nozzle at full width (mil) & 56.5 & 50.5 \\
\hline & Effective outer plate gap to nozzle at full width (mil) & 61.5 & 55.5 \\
\hline
\end{tabular}


ANL/GTRI/TM-13/6

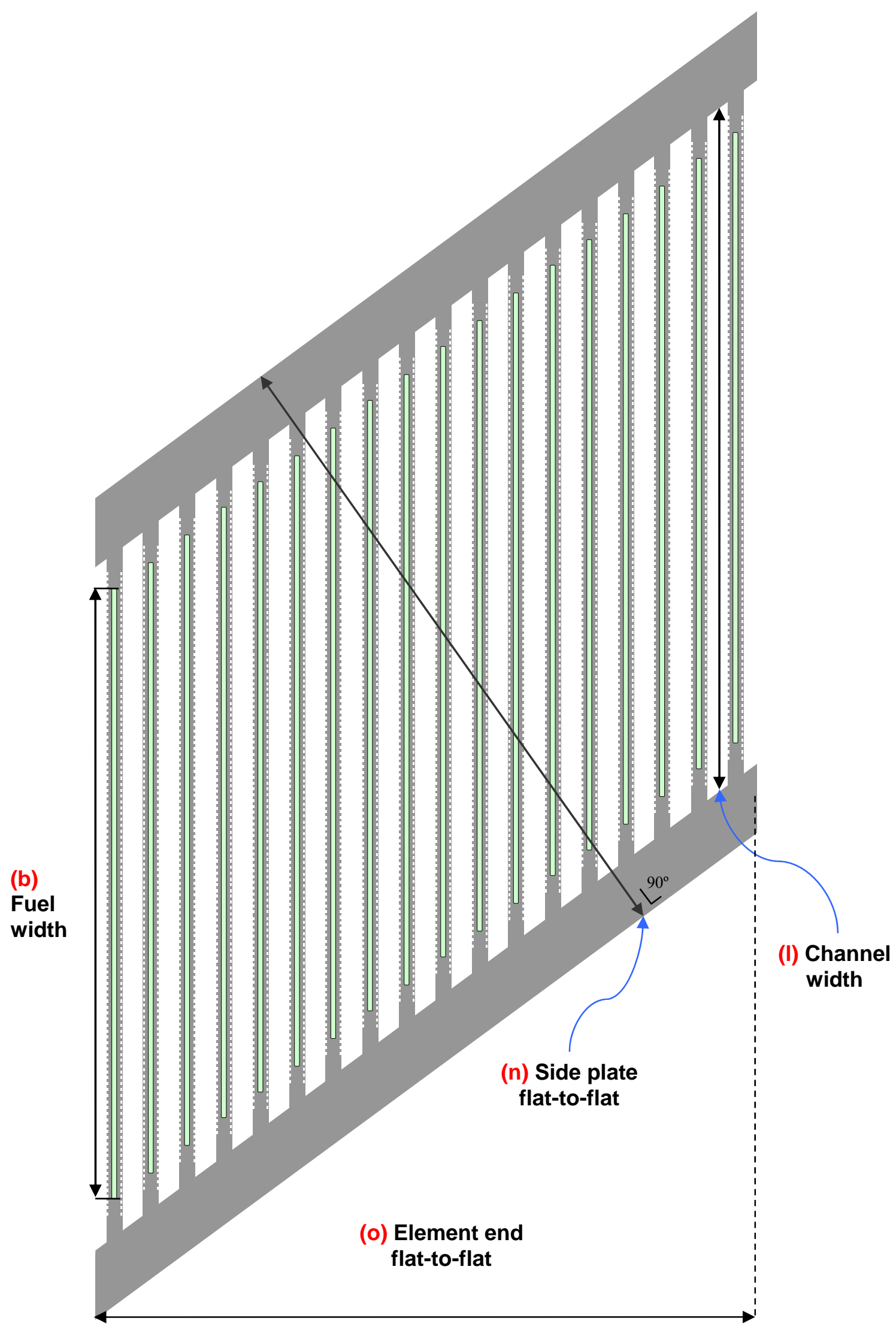

Figure 2.2. Schematic of MITR LEU fuel element drawn with 18 plates. (letters indicate dimensions listed in Table 2.1) 


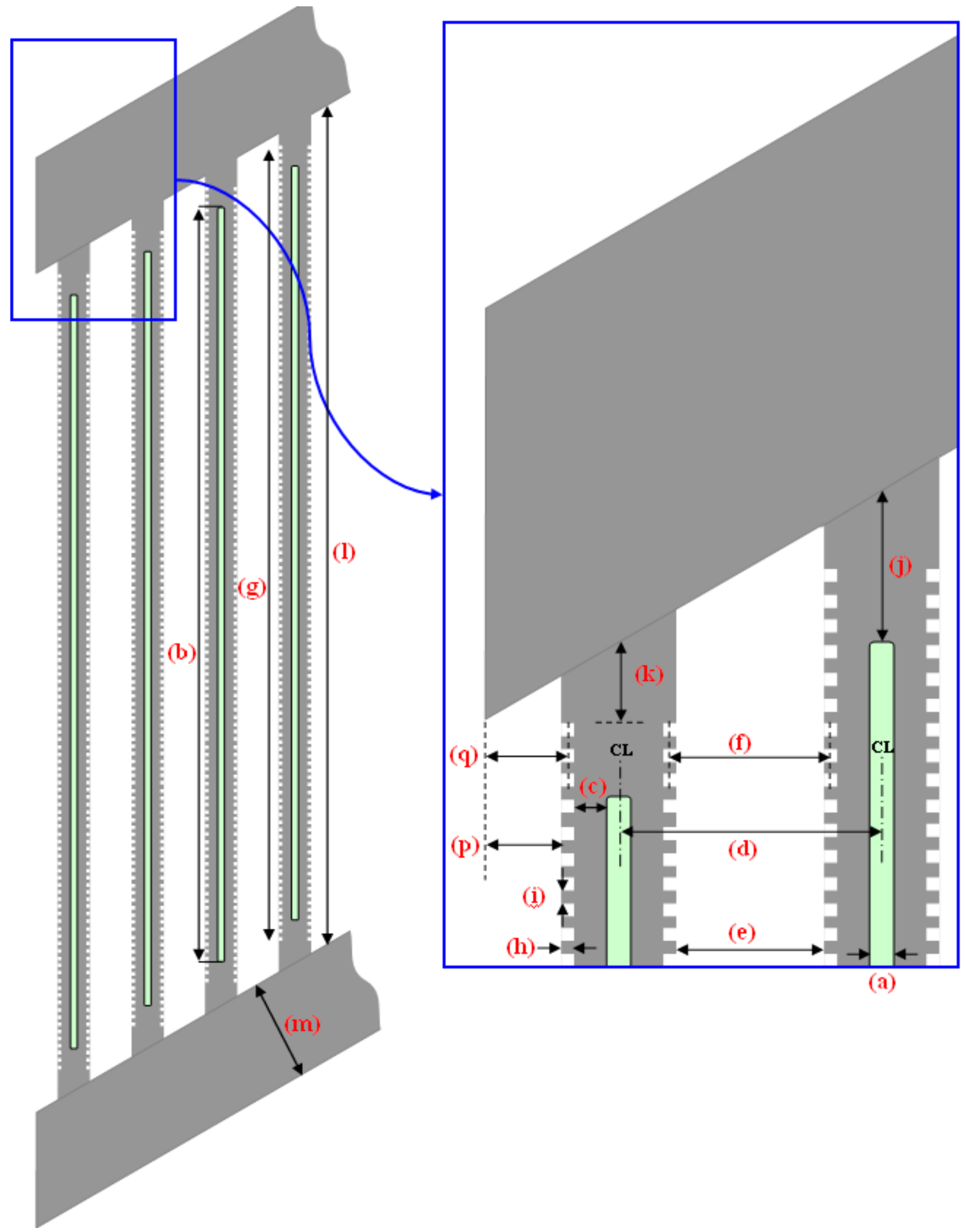

Figure 2.3. Schematic of MITR LEU fuel element (outer 4 of 18 plates shown). (letters indicate dimensions listed in Table 2.1) 


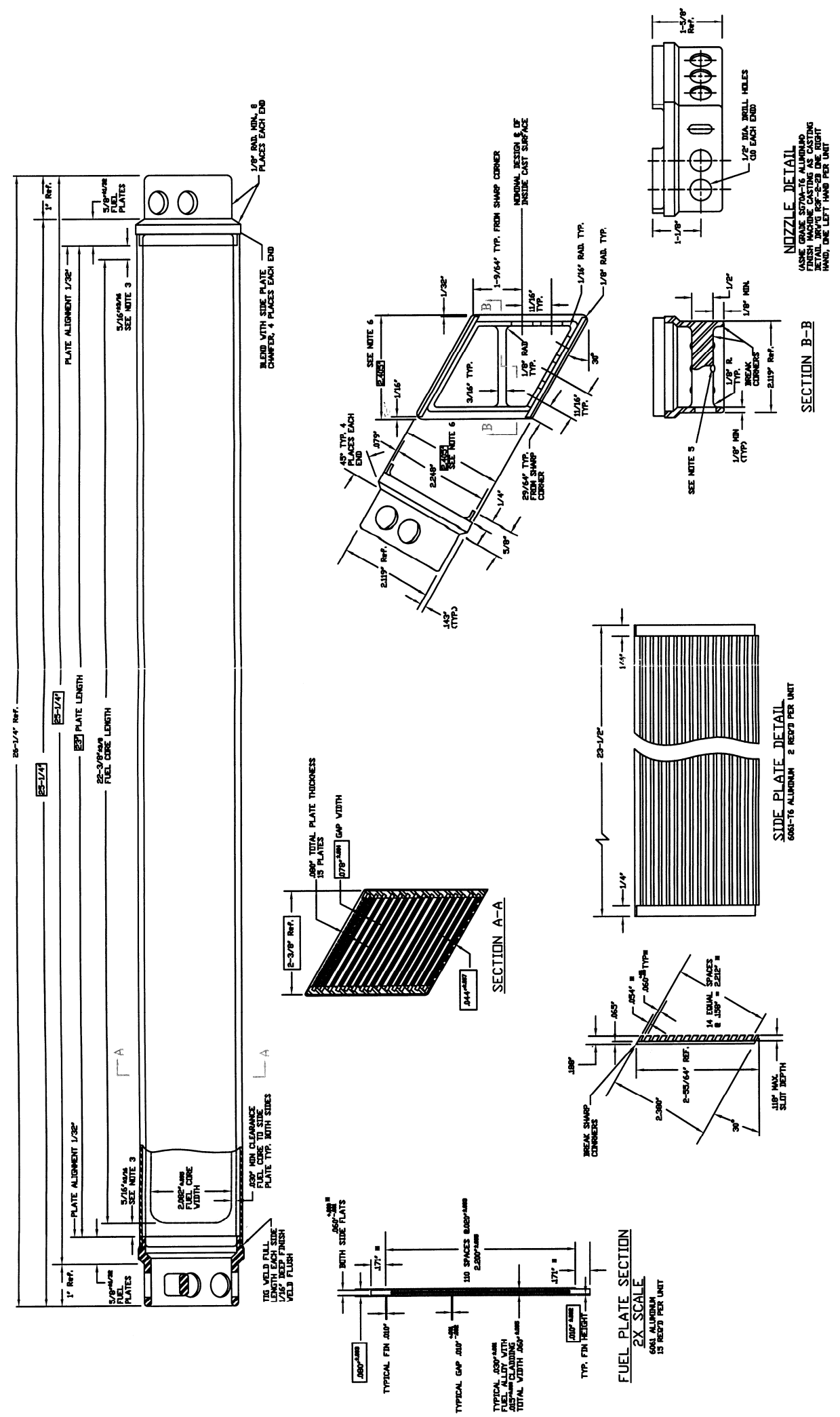

Figure 2.4. HEU fuel element MITR specification R3F-201-4. 


\subsection{Element Design Parameters and Tolerances}

Dimensional tolerances for HEU and assumed LEU values are listed for the element plates and interior channels in Table 2.2 [8]. The open channels on the outside of each element end are referred to as end channels, and dimensional tolerances for HEU and assumed for LEU are listed in Table 2.3 [8].

Table 2.4 summarizes fuel design and performance parameters, and associated tolerances, for the current HEU and the proposed LEU element [8,12,13]. The fuel design, measurement uncertainties, and fabrication tolerances are crucial parameters for the performance and safety analyses. For each parameter, the table provides the HEU fuel specification, the corresponding value assumed or required for the LEU analysis, the relevant GTRI pillar, and the portion of the Safety Analysis Report (SAR) impacted by the data. Items which are anticipated to be required include 1) a U.S. Nuclear Regulatory Commission (NUREG) Safety Evaluation Report for the monolithic U-Mo alloy fuel, 2) a fuel specification specific for MITR analogous to [12] consistent with sufficient manufacturing data, 3) Design Demonstration Experiment (DDE) irradiation results of one or more partial or full MITR elements in relevant test conditions, and 4) flow testing of a full MITR element prototype.

It is noteworthy that in addition to fuel homogeneity which is an areal measurement integrating the UMo density through the thickness of the fuel, there are additional sources of ${ }^{235} \mathrm{U}$ variation. It is assumed that both the ${ }^{235} \mathrm{U}$ enrichment, and the molybdenum homogeneity in the fuel, are reasonably uniform on the length scale of interest for MITR. In MITR the length scale used for thermal conduction is approximately 0.5 inches as shown in the lateral stripe size used in safety analyses [4]. Thus, over any 0.5 inch region an assumption for ${ }^{235} \mathrm{U}$ enrichment is taken to be $19.75 \mathrm{wt} \% \pm 0.2 \mathrm{wt} \%$ from [14], and molybdenum homogeneity in the fuel is assumed to be $10 \mathrm{wt} \% \pm 1 \mathrm{wt} \%$ Mo in U10Mo. Given these assumed specifications for ${ }^{235} \mathrm{U}$ enrichment and molybdenum in U10Mo, the impact on safety analysis limits is minor, and fuel cycle performance should only be affected if a significant fraction is not distributed normally about the nominal specification targets. Table 2.4 is derived principally from [8] with the addition of these assumptions as well as a surface roughness specification.

Preliminary accident analyses are underway to estimate anticipated temperatures for the LEU element designs. Off-normal transient and accident analyses may revise the temperatures expected during transients from those temperatures listed in the table.

Another parameter of interest is the fission product release fractions from a monolithic U-Mo LEU fuel plate. U10Mo properties, as well the metallic matrix, differ from the U-Al $\mathrm{x}_{\mathrm{x}}$ matrix of the $\mathrm{HEU}$ fuel. Hence, the fission product retention characteristics during a Maximum Hypothetical Accident (MHA) will vary to some degree relative to the current $\mathrm{U}-\mathrm{Al}_{\mathrm{x}}$ dispersion fuel. Although the impact of a conservative approach for MHA release is being analyzed, experimental release data for the various groups could potentially prove helpful. In particular, iodine is assumed to have a 0.9 release fraction for HEU and in preliminary LEU analyses, and so a measurement of the release fraction of iodine could prove modestly beneficial to establish potential dose consequences.

Additionally, flow testing of the LEU fuel plates, which are thinner and have a different fuel meat/core than the HEU fuel plates, is needed to ensure mechanical stability in the MITR thermal-hydraulic environment. This is planned to occur during a series of flow testing in the Oregon State University Hydromechanical Test Facility (HMFTF) as listed in Table 2.4. 
Table 2.2. Tolerance summary of HEU and LEU fuel plate and full-channel (interior channel) dimensions.

\begin{tabular}{|l|c|c|}
\hline \multicolumn{1}{|c|}{ Plate and channel dimensions } & HEU & LEU \\
\hline Fuel meat width (inch) & $2.082+/-0.095$ & $2.082+/-0.095$ \\
\hline Fuel meat thickness (mil) & $30+/-1$ & $20+/-1$ \\
\hline $\begin{array}{l}\text { Clad thickness Al+Zr (mil) } \\
\text { (base of fin to fuel surface) }\end{array}$ & $15+/-3$ & $60+/-3$ \\
\hline $\begin{array}{l}\text { Plate thickness in un-finned section, unscratched } \\
\text { (mil) }\end{array}$ & $80+/-3$ & $40+/-3$ \\
\hline Plate thickness at fin base, unscratched (mil) & $60+/-5$ & $72+/-4$ \\
\hline Water gap (fin tip-to-tip) (mil) & $78+/-4$ & $72+/-7$ \\
\hline $\begin{array}{l}\text { Local water gap at any one measurement point } \\
\text { (fin tip-to-tip) (mil) }\end{array}$ & $78+/-7$ & $2.2+/-0.005$ \\
\hline Finned width (inch) & $2.2+/-0.005$ & 220 \\
\hline Number of fins per plate & 220 & $10+/-0.02$ \\
\hline Fin height (mil) & $10+/-0.02$ & $20+/-0.03$ \\
\hline Fin pitch (mil) & $20+/-0.03$ & $2.308+/-0.01$ \\
\hline Channel width (inch) & $2.308+/-0.01$ & \\
\hline
\end{tabular}

Table 2.3. Tolerance summary of HEU and LEU end channel (outside channel) dimensions.

\begin{tabular}{|l|c|c|}
\hline \multicolumn{1}{|c|}{ Plate and channel dimensions } & HEU & LEU \\
\hline End channels per assembly & 2 & $38+/-4$ \\
\hline $\begin{array}{l}\text { End channel water gap for fuel plate to side plate } \\
\text { neighboring elements (fin tip to fin tip) (mil) }\end{array}$ & $44+/-7$ & $38+/-7$ \\
\hline $\begin{array}{l}\text { Local end channel water gap at any one } \\
\text { measurement point (fin tip to side plate end plane) } \\
\text { (mil) }\end{array}$ & $44+/-7$ & 2 \\
\hline
\end{tabular}


ANL/GTRI/TM-13/6

Table 2.4. Summary of element design parameters and tolerances.

\begin{tabular}{|c|c|c|c|c|}
\hline Parameter & HEU Specification & LEU Analysis Assumes/Requires & GTRI Pillar & $\begin{array}{c}\text { Required for SAR } \\
\text { Analysis } \\
\end{array}$ \\
\hline $\begin{array}{l}\text { Interior Channel Thickness } \\
\text { (fin tip to tip, interior channel) }\end{array}$ & $78 \mathrm{mil} \mathrm{+/-} 4$ mil & 72 mil \pm 4 mil & FFC & $\begin{array}{c}\text { Thermal hydraulic Hot } \\
\text { Channel Factors } \\
\text { (HCF) / transients }\end{array}$ \\
\hline $\begin{array}{l}\text { Local Interior Channel Thickness } \\
\text { (fin tip to tip, interior channel) }\end{array}$ & 78 mil +/- 7 mil & $72 \mathrm{mil} \pm 7$ mil & FFC & $\mathrm{HCF} /$ transients \\
\hline $\begin{array}{l}\text { End (non-interior) Channel Thickness } \\
\text { (fin tip to side plate end plane) }\end{array}$ & 44 mil +/- 7 mil & 38 mil +/- 4 mil (tolerance more stringent than HEU) & FFC & $\begin{array}{l}\text { End channel HCF / } \\
\text { transients }\end{array}$ \\
\hline $\begin{array}{l}\text { Local End Channel Thickness } \\
\text { (fin tip to side plate end plane) }\end{array}$ & $44 \mathrm{mil} \mathrm{+/-} 7 \mathrm{mil}$ & $\begin{array}{l}38 \mathrm{mil}+/-7 \text { mil; number of measurement } \\
\text { points similar to interior channel }\end{array}$ & FFC & $\mathrm{HCF} /$ transients \\
\hline $\begin{array}{c}\text { Fuel Homogeneity } \\
(0.08 \text { inch diameter area) }\end{array}$ & $\begin{array}{c}\text { Density }+25 \% /-35 \% \text { from } \\
\text { density standard }\end{array}$ & Same as HEU & FFC & $\mathrm{HCF}$ \\
\hline $\begin{array}{c}\text { Fuel Homogeneity } \\
(0.5 \text { inch diameter area })\end{array}$ & $\begin{array}{c}\text { Density }+/-10 \% \text { from } \\
\text { density standard }\end{array}$ & Same as HEU & FFC & $\mathrm{HCF}$ \\
\hline $\begin{array}{l}\text { Plate U-235 Fuel Loading } \\
\text { Element U-235 Fuel Loading }\end{array}$ & $\begin{array}{c}34.0 \mathrm{~g}+0.2 /-1.0 \mathrm{~g} \\
510+3 /-10 \mathrm{~g} \\
\end{array}$ & $\begin{array}{l}46.2+0.3 /-1.5 \mathrm{~g} \\
831+5.0 /-16.3 \mathrm{~g} \\
\end{array}$ & FFC & Nuclear design \\
\hline${ }^{235} \mathrm{U}$ Enrichment & Plate enrichment & $19.75 \pm 0.2 \mathrm{wt} \%$ & FFC & $\mathrm{HCF}$ \\
\hline Fuel Alloy & $\mathrm{UAl}_{2}, \mathrm{UAl}_{3}, \mathrm{UAl}_{4}$ measured & U-Mo; Mo content $10 \pm 1 \mathrm{wt} \%$ & FFC & $\mathrm{HCF}$ \\
\hline Fuel Meat Thickness & $30 \mathrm{mil}$ & $20 \pm 1 \mathrm{mil}$ & FFC & $\mathrm{HCF}$ \\
\hline Surface Roughness & Element drawings & $\leq 125 \mu$-inch & FFC & Thermal hydraulic \\
\hline Clad, scratch max. depth & $<6$ mils fin, $<3$ mils groove & Tolerance must meet license requirements & FFC & No analysis \\
\hline Bond Integrity & TRTR-3 v.1 [13] & Debond characterization and tolerances TBD & FFC & No analysis \\
\hline Fuel Specification & TRTR-3 v.1 [13] & LEU fuel spec including parameters above & FFC & Reference \\
\hline Fuel Qualification by NRC & Historic Application & $\begin{array}{c}20 \text { mil U10Mo with } 10 \text { mil nominal clad at base of fins } \\
\text { and } 8 \text { mil minimum clad ( } 5 \text { mil with scratch). Clad } \\
\text { thickness includes } \mathrm{Zr} \text { interlayer thickness. No fission } \\
\text { density limit. Fuel integrity not limited }<450^{\circ} \mathrm{C}\end{array}$ & FD & $\begin{array}{c}\text { NUREG }+ \\
\text { DDE in SAR appendix }\end{array}$ \\
\hline Fuel Fission Density Limit & $2.3 \times 10^{21}$ fissions $/ \mathrm{cm}^{3}$ & $<7.8 \times 10^{21}$ fissions $/ \mathrm{cm}^{3}$ & FD & NUREG \\
\hline $\begin{array}{c}\text { Fission Product Release Fraction from } \\
\text { Fuel to Coolant }\end{array}$ & $\begin{array}{l}\text { Nobles } 1, \text { I Cs } 0.9, \text { Te } 0.23 \\
\text { Sr Ba Ru } 0.01 \text {, others } 1 \mathrm{e}-4\end{array}$ & Impact of conservative approach is being analyzed. & FD & Source Term \\
\hline HMFTF, MITR Plate Deformation & Not observed during testing & $\begin{array}{l}\text { Acceptable elastic deformation } \\
\text { No plastic deformation }\end{array}$ & HMFTF & SAR Appendix \\
\hline $\begin{array}{c}\text { HMFTF, Measured Flow Disparity } \\
\text { within an MITR Element }\end{array}$ & Measured 0.929 disparity & \begin{tabular}{|l|} 
Measurement of 18 plate prototype flow disparity for \\
19 channels ( 17 interior / 2 outside); as-built thickness
\end{tabular} & $\begin{array}{l}\text { HMFTF/ } \\
\text { FFC }\end{array}$ & $\mathrm{HCF}$ \\
\hline Oxide Thickness & $<2$ mil & Data analysis limits TBD & RC-MITR & Reactivity transient \\
\hline
\end{tabular}




\subsection{STEADY STATE LEU OPERATIONS DATA}

The MITR is currently licensed for a maximum steady-state power level of $6 \mathrm{MW}$. This power level provides neutron flux levels primarily for experiments using neutron beams and in-core irradiation facilities. It delivers a neutron flux and energy spectrum comparable to current LWR power reactors in a compact $6 \mathrm{MW}$ core using Highly Enriched Uranium (HEU) fuel.

The goal of the conversion to LEU fuel is to develop a fuel element design that will ensure safe reactor operations, as well as maintaining existing performance. The LEU fuel was designed according to a set of manufacturing assumptions that were provided by the FD and FFC pillars of the RERTR program to reliably manufacture the fuel plates. The LEU core would operate at a power of $7 \mathrm{MW}$ to continue to meet the facility mission [1,15], and so the data provided here is based on safety analysis calculations for a reactor to operate at an LEU steady state nominal operating power of $7 \mathrm{MW}$.

The calculated heat flux profiles presented in [4] are based on $\mathrm{f7}$ tallies in MCNP, which assume all heat resulting from fission is deposited at the site of the fission event (i.e., in the fuel meat). Furthermore, the results assume a core power level of $7 \mathrm{MW}$ (core includes the fuel plates and associated coolant). That is, the contribution of nuclear heating in the reflector and other ex-core components to the total reactor plant power was neglected in the power normalization. It was calculated that the fraction of the plant power generated in ex-core structures is $0.3 \mathrm{MW}$ of the total. The minor contributions from energy deposited in cladding and water have been conservatively included in the fuel plate. Consequently, for the thermal hydraulic results, the heat flux and heat generation rate profiles in the fuel have been normalized to a core power level of approximately 6.7 MW; however, power distribution results presented here are unnormalized and correspond to $7 \mathrm{MW}$ power in the fuel.

In this report, irradiation parameters are presented for the LEU elements under the conditions that are expected in steady-state operations to represent the highest plate heat flux, fuel and clad temperatures, fission rate density, and cumulative fission density. In order to characterize these over a range of MITR LEU core configurations, a set of depleted cores was generated with fuel management analogous to current HEU operations [4]. The most limiting case, in terms of both power and thermal hydraulics was found for a depleted MITR LEU Core 189, and is described below [9]. Since this data was originally compiled for irradiation in a geometry identical to the MITR design that would serve as a prototype partial MITR LEU element, heat flux was used to describe the power distributions [16]. A conversion to fission rate will be discussed after heat flux data is presented in the following sections.

\subsection{Calculation Methodology}

Power distributions for the power profiles reported are based upon an MCODE [17] depletion using ORIGEN2 [18] and MCNP5 [19] with independently depleting spatial zones in as given in Table 3.1. All calculations of heat flux are based upon an area of fuel meat (referred to as foil for LEU) without considering any additional area for the fins or un-fueled regions on either side of the foil. Thus, the area used to calculate heat flux from the fueled portion of each plate is both sides of the fuel meat zone 22.375 inches in length and 2.082 inches in width. Consideration of the additional heat transfer provided by fins is not taken into account during calculation of power distributions, but instead in the thermal hydraulic modeling of MITR. 
Table 3.1. Discretization of the LEU depletion zones and power regions used to generate neutronic power shapes in the peak plates.

\begin{tabular}{|c|c|c|c|}
\hline $\begin{array}{c}\text { Spatial } \\
\text { Regions }\end{array}$ & MCNP Model Geometry & Depletion & Power Shape \\
\hline $\begin{array}{c}\text { Fuel foil axial region } \\
\text { (cm of foil) }\end{array}$ & Continuous & 9.47 & 3.16 \\
\hline $\begin{array}{c}\text { Fuel foil lateral region } \\
\text { (cm of foil) }\end{array}$ & Continuous & 5.29 & 1.32 \\
\hline
\end{tabular}

Power distributions are generated by dividing the 2.082 inch fuel zone width into four equal lateral stripes which are transverse to the flow direction. The four stripes were shown in [4] to represent the power peaking at the outside of each plate without explicitly taking into account lateral heat conduction. Since the lateral division is based upon this analysis, the results presented in this work are intended only for use in a thermal hydraulic analysis which does not explicitly model or otherwise incorporate the effects of lateral heat conduction.

A comparative basis should be maintained between the calculations referenced in this work that will form the LEU safety basis, and the irradiation experiments used to qualify U10Mo fuel for the MITR and other reactors. For the MITR Design Demonstration Experiment (DDE) it was recommended that the starting basis for the size scale of regions of depletion and power distribution correspond with those used in the MITR analyses up to that point in order to represent the various physical phenomena accounted for in the safety basis calculations [16]. Where variations exist the DDE irradiation planning should compare results based on the discretization presented in this work in order to ensure that alterations do not impact accurate modeling of the underlying phenomena. Many of the same parameters presented for the DDE remain relevant to irradiations that are not in the specific MITR geometry and so are also presented in this work.

With the discretization used for generation of the power distributions, each axial region is $3.16 \mathrm{~cm}$ tall, and each stripe $1.32 \mathrm{~cm}$ wide laterally along the whole axial length of each plate. Thus with 18 axial regions, the smallest region is the intersection of these comprising a region of $4.17 \mathrm{~cm}^{2}$ of fuel meat area which is referred to as a "location" or "spot". 


\subsection{Heat Flux and Fission Rate Density}

The most limiting power profile for is the maximum power stripe of Core 189 End of Cycle (EOC), where Figure 3.1 and Table 3.2 give the axial heat flux profile of this stripe for a $7 \mathrm{MW}$ core power. The same plate contains the single location (spot) of maximum heat flux at the beginning of cycle- Core 189 Beginning of Cycle (BOC). The power distribution for the entire plate containing these peak locations is shown in Figures 3.2 and 3.3, and is listed in Table 3.3 for a $7 \mathrm{MW}$ core power. In these power profiles the peak stripe power is $57.2 \mathrm{~W} / \mathrm{cm}^{2}$ of foil (axially-averaged), and the peak single location is a spot with $76.6 \mathrm{~W} / \mathrm{cm}^{2}$ of foil. Various extrema and peaking factors for Core 189 are listed in Table 3.4 for the same peak plate listed in Table 3.3. The peaking factor "stripe peaking within plate" is defined as the average heat flux of a stripe (a fuel foil is divided into four equal stripes along the 2.082 inch width) divided by the average heat flux of the plate in which the stripe resides. The peaking factor "local peaking within stripe" is defined as the local heat flux of a spot divided by the average heat flux of the stripe in which the spot resides (a spot is one segment of a stripe after division into 18 axial segments).

Since the MITR design has only a single foil thickness, the highest fission rate density is found in the same location as the region of highest heat flux $\left(76.6 \mathrm{~W} / \mathrm{cm}^{2}\right.$ of foil). This yields a peak volumetric heating of $3016 \mathrm{~W} / \mathrm{cm}^{3}$ corresponding to a peak fission rate of $9.3 \times 10^{13} \mathrm{~cm}^{-3} \mathrm{~s}^{-1}$. Other values in this report may be similarly converted. This value represents the spatial nodalization made for safety analysis calculations. Additional details regarding lateral power peaking and fission rate densities are discussed in Section 3.2.2.

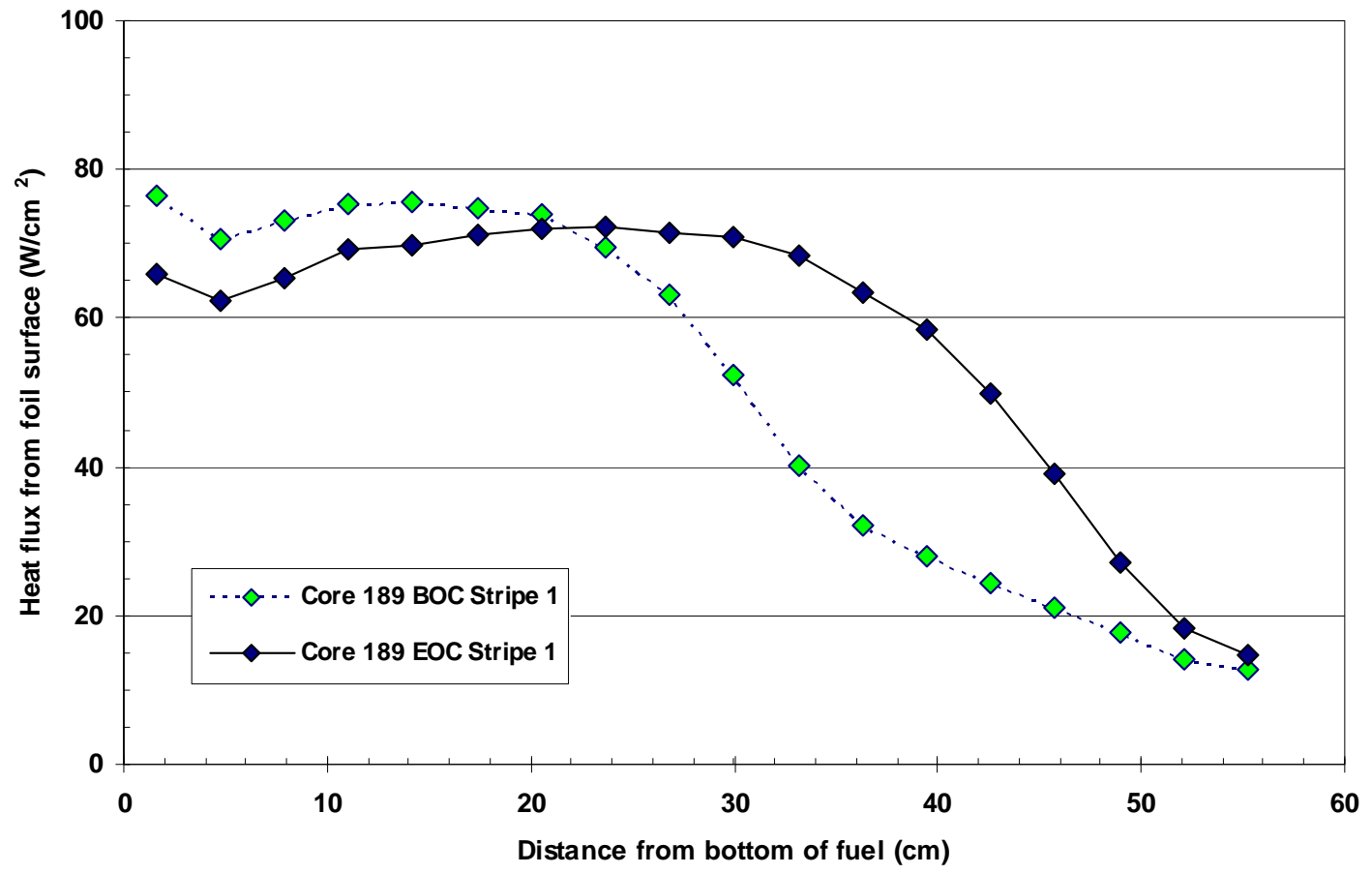

Figure 3.1. Axial heat flux profile of location (Core 189 BOC) and stripe (Core $189 \mathrm{EOC}$ ) of maximum heat flux. 


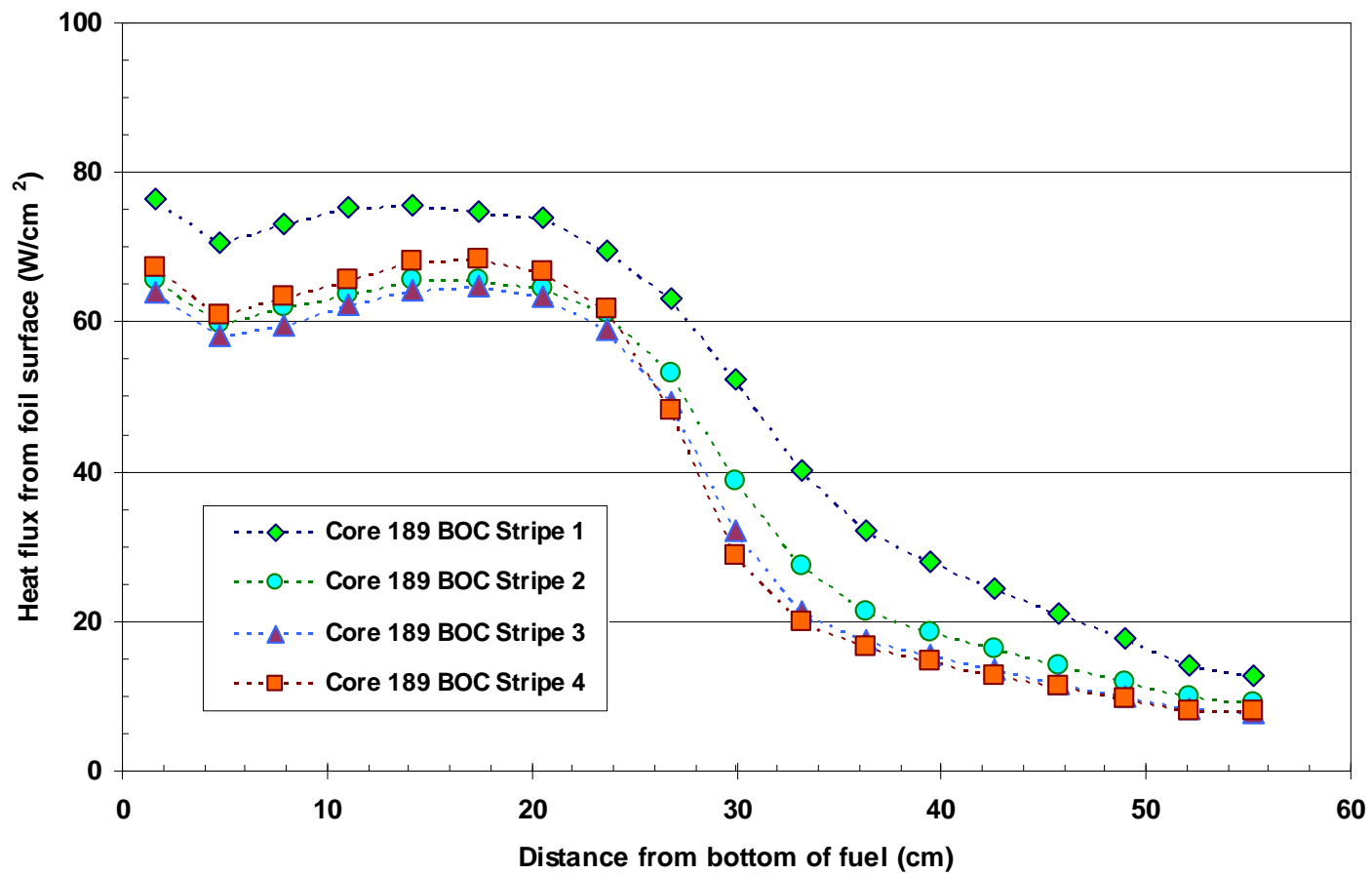

Figure 3.2. Axial heat flux profile of LEU plate with location of maximum heat flux.

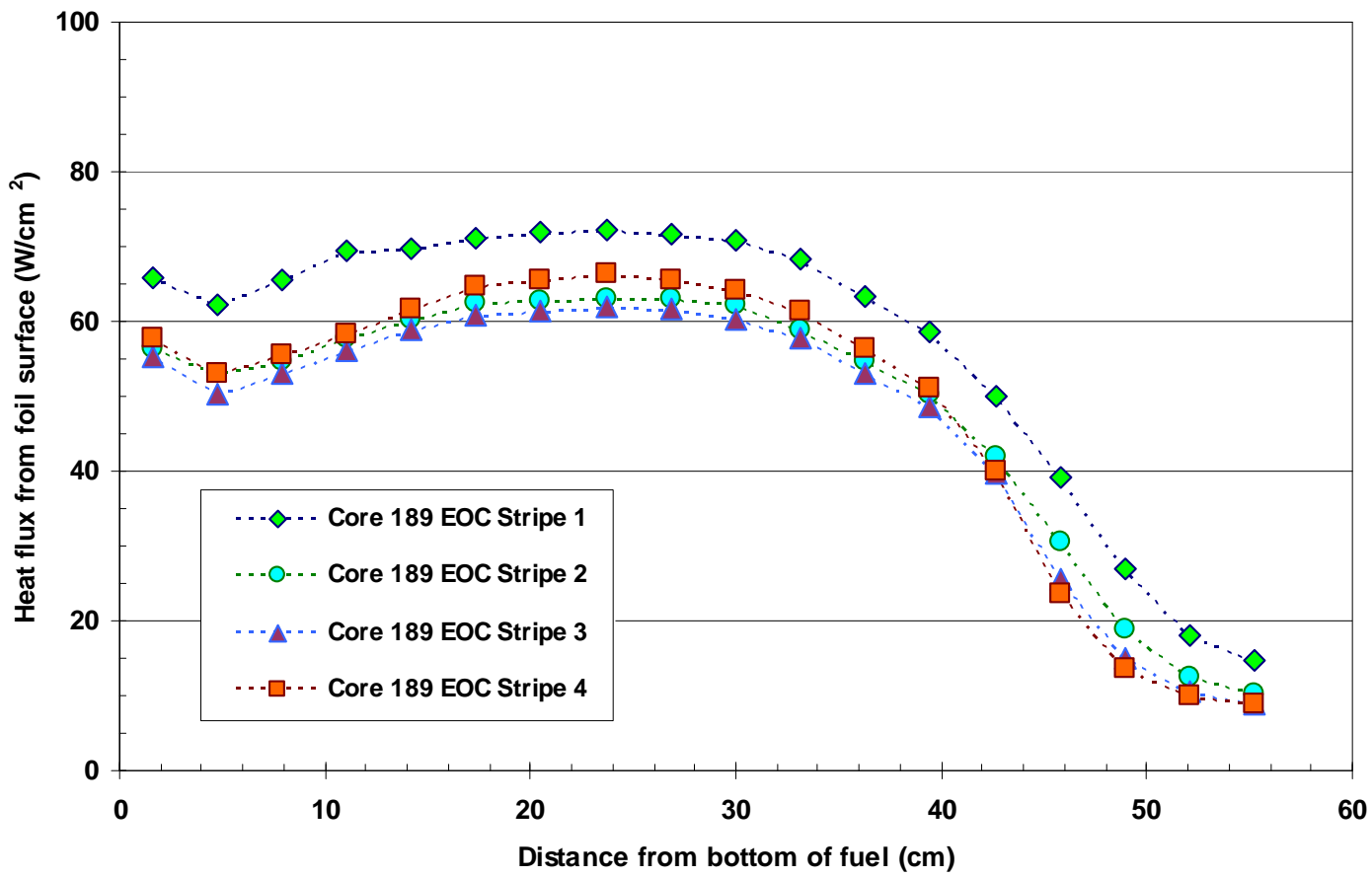

Figure 3.3. Axial heat flux profile of LEU plate with stripe of maximum heat flux. 
Table 3.2. Axial heat flux distributions of $7 \mathrm{MW}$ LEU cores with locations of maximum power.

\begin{tabular}{|c|c|c|}
\hline \multirow[b]{2}{*}{$\begin{array}{c}\text { Axial Node } \\
\text { Center from } \\
\text { Bottom of Fuel } \\
(\mathrm{cm})\end{array}$} & \multicolumn{2}{|c|}{ Heat Flux (W/ $\mathrm{cm}^{2}$ of foil) } \\
\hline & $\begin{array}{c}\text { Stripe with } \\
\text { Peak Spot } \\
\text { (Core 189 BOC Stripe 1) }\end{array}$ & $\begin{array}{c}\text { Peak Stripe } \\
\text { (Core 189 EOC Stripe 1) }\end{array}$ \\
\hline 55.3 & 12.8 & 14.6 \\
\hline 52.1 & 14.2 & 18.2 \\
\hline 48.9 & 17.7 & 27.1 \\
\hline 45.8 & 21.0 & 39.1 \\
\hline 42.6 & 24.4 & 50.0 \\
\hline 39.5 & 28.0 & 58.6 \\
\hline 36.3 & 32.1 & 63.3 \\
\hline 33.2 & 40.2 & 68.5 \\
\hline 30.0 & 52.4 & 70.9 \\
\hline 26.8 & 63.1 & 71.6 \\
\hline 23.7 & 69.6 & 72.2 \\
\hline 20.5 & 73.9 & 71.9 \\
\hline 17.4 & 74.8 & 71.1 \\
\hline 14.2 & 75.7 & 69.7 \\
\hline 11.1 & 75.3 & 69.3 \\
\hline 7.9 & 73.0 & 65.5 \\
\hline 4.7 & 70.6 & 62.3 \\
\hline 1.6 & 76.6 & 66.0 \\
\hline $\begin{array}{l}\text { Stripe Average } \\
\left(\mathrm{W} / \mathrm{cm}^{2} \text { of foil) }\right.\end{array}$ & 49.7 & 57.2 \\
\hline
\end{tabular}

${ }^{a}$ Top of LEU fuel foil in upflow reactor is at $223 / 8$ inch $(56.8325 \mathrm{~cm})$.

${ }^{\mathrm{b}}$ Bottom of LEU fuel foil upflow reactor is at zero. 
Table 3.3. Axial heat flux distributions of $7 \mathrm{MW}$ LEU cores in plate with locations of maximum power.

\begin{tabular}{|c|c|c|c|c|c|c|c|c|}
\cline { 2 - 9 } \multicolumn{1}{c|}{} & \multicolumn{9}{|c|}{ Heat Flux (W/cm of foil) } \\
\hline $\begin{array}{c}\text { Axial Node Center } \\
\text { from Bottom of Fuel } \\
\text { (cm) }\end{array}$ & $\begin{array}{c}\text { Core 189 } \\
\text { BOC } \\
\text { Stripe 1 }\end{array}$ & $\begin{array}{c}\text { Core 189 } \\
\text { BOC } \\
\text { Stripe 2 }\end{array}$ & $\begin{array}{c}\text { Core 189 } \\
\text { BOC } \\
\text { Stripe 3 }\end{array}$ & $\begin{array}{c}\text { Core 189 } \\
\text { BOC } \\
\text { Stripe 4 }\end{array}$ & $\begin{array}{c}\text { Core 189 } \\
\text { EOC } \\
\text { Stripe 1 }\end{array}$ & $\begin{array}{c}\text { Core 189 } \\
\text { EOC } \\
\text { Stripe 2 }\end{array}$ & $\begin{array}{c}\text { Core 189 } \\
\text { EOC } \\
\text { Stripe 3 }\end{array}$ & $\begin{array}{c}\text { Core 189 } \\
\text { EOC } \\
\text { Stripe 4 }\end{array}$ \\
\hline $55.3^{\text {a }}$ & 12.8 & 9.2 & 7.9 & 8.1 & 14.6 & 10.4 & 8.9 & 8.9 \\
\hline 52.1 & 14.2 & 9.9 & 8.3 & 8.1 & 18.2 & 12.4 & 10.4 & 9.9 \\
\hline 48.9 & 17.7 & 12.0 & 9.9 & 9.6 & 27.1 & 19.0 & 15.0 & 13.7 \\
\hline 45.8 & 21.0 & 14.1 & 11.7 & 11.2 & 39.1 & 30.5 & 25.5 & 23.7 \\
\hline 42.6 & 24.4 & 16.4 & 13.5 & 12.8 & 50.0 & 42.0 & 39.7 & 40.0 \\
\hline 39.5 & 28.0 & 18.5 & 15.4 & 14.6 & 58.6 & 50.3 & 48.7 & 51.2 \\
\hline 36.3 & 32.1 & 21.4 & 17.4 & 16.5 & 63.3 & 54.6 & 53.0 & 56.4 \\
\hline 33.2 & 40.2 & 27.3 & 21.3 & 19.9 & 68.5 & 58.8 & 57.9 & 61.3 \\
\hline 30.0 & 52.4 & 38.9 & 32.1 & 28.8 & 70.9 & 62.1 & 60.3 & 64.1 \\
\hline 26.8 & 63.1 & 53.0 & 49.3 & 48.2 & 71.6 & 63.0 & 61.8 & 65.5 \\
\hline 23.7 & 69.6 & 61.1 & 59.1 & 61.8 & 72.2 & 62.9 & 62.0 & 66.3 \\
\hline 20.5 & 73.9 & 64.6 & 63.4 & 66.8 & 71.9 & 62.7 & 61.5 & 65.6 \\
\hline 17.4 & 74.8 & 65.7 & 64.8 & 68.6 & 71.1 & 62.4 & 61.0 & 64.6 \\
\hline 14.2 & 75.7 & 65.7 & 64.3 & 68.2 & 69.7 & 60.2 & 58.8 & 61.6 \\
\hline 11.1 & 75.3 & 63.8 & 62.2 & 65.7 & 69.3 & 57.8 & 56.2 & 58.4 \\
\hline 7.9 & 73.0 & 62.1 & 59.6 & 63.5 & 65.5 & 54.8 & 53.1 & 55.7 \\
\hline 4.7 & 70.6 & 59.9 & 58.2 & 60.9 & 62.3 & 53.0 & 50.4 & 53.0 \\
\hline 1.6 & 76.6 & 65.7 & 64.1 & 67.4 & 66.0 & 56.5 & 55.2 & 57.8 \\
\hline Stripe Average & 49.7 & 40.5 & 37.9 & 38.9 & 57.2 & 48.5 & 46.6 & 48.8 \\
\hline
\end{tabular}

${ }^{\text {a }}$ Top of LEU fuel foil in upflow reactor is at $223 / 8$ inch $(56.8325 \mathrm{~cm})$.

${ }^{\mathrm{b}}$ Bottom of LEU fuel foil in upflow reactor is at zero.

Table 3.4. Extrema and peaking in plate of $7 \mathrm{MW}$ LEU cores with locations of maximum power.

\begin{tabular}{|c|c|c|c|c|c|c|c|c|}
\hline & $\begin{array}{c}\text { Core } 189 \\
\text { BOC } \\
\text { Stripe 1 } \\
\end{array}$ & $\begin{array}{c}\text { Core } 189 \\
\text { BOC } \\
\text { Stripe } 2 \\
\end{array}$ & $\begin{array}{c}\text { Core } 189 \\
\text { BOC } \\
\text { Stripe } 3 \\
\end{array}$ & $\begin{array}{c}\text { Core } 189 \\
\text { BOC } \\
\text { Stripe } 4 \\
\end{array}$ & $\begin{array}{c}\text { Core } 189 \\
\text { EOC } \\
\text { Stripe } 1 \\
\end{array}$ & $\begin{array}{c}\text { Core } 189 \\
\text { EOC } \\
\text { Stripe } 2 \\
\end{array}$ & $\begin{array}{c}\text { Core } 189 \\
\text { EOC } \\
\text { Stripe } 3 \\
\end{array}$ & $\begin{array}{c}\text { Core } 189 \\
\text { EOC } \\
\text { Stripe } 4 \\
\end{array}$ \\
\hline $\begin{array}{l}\text { Local Peaking } \\
\text { within Stripe }\end{array}$ & 1.54 & 1.62 & 1.71 & 1.76 & 2.26 & 1.30 & 1.33 & 1.36 \\
\hline $\begin{array}{c}\text { Stripe Peaking } \\
\text { within Plate }\end{array}$ & 1.19 & 0.97 & 0.91 & 0.93 & 1.14 & 0.97 & 0.93 & 0.97 \\
\hline $\begin{array}{c}\text { Average } \\
\text { Power in Plate }\end{array}$ & \multicolumn{4}{|c|}{$\begin{array}{c}41.8 \\
\mathrm{~W} / \mathrm{cm}^{2} \text { of foil } \\
\end{array}$} & \multicolumn{4}{|c|}{$\begin{array}{c}50.3 \\
\mathrm{~W} / \mathrm{cm}^{2} \text { of foil } \\
\end{array}$} \\
\hline $\begin{array}{c}\text { Peak Stripe } \\
\text { Power in Plate }\end{array}$ & \multicolumn{4}{|c|}{$\begin{array}{c}49.7 \\
\mathrm{~W} / \mathrm{cm}^{2} \text { of foil }\end{array}$} & \multicolumn{4}{|c|}{$\begin{array}{c}57.2 \\
\mathrm{~W} / \mathrm{cm}^{2} \text { of foil }\end{array}$} \\
\hline $\begin{array}{c}\text { Peak Power in } \\
\text { Plate }\end{array}$ & \multicolumn{4}{|c|}{$\begin{array}{c}76.6 \\
\mathrm{~W} / \mathrm{cm}^{2} \text { of foil }\end{array}$} & \multicolumn{4}{|c|}{$\begin{array}{c}72.2 \\
\mathrm{~W} / \mathrm{cm}^{2} \text { of foil }\end{array}$} \\
\hline $\begin{array}{l}\text { Minimum } \\
\text { Stripe Power } \\
\text { in Plate }\end{array}$ & \multicolumn{4}{|c|}{$\begin{array}{c}37.9 \\
\mathrm{~W} / \mathrm{cm}^{2} \text { of foil }\end{array}$} & \multicolumn{4}{|c|}{$\begin{array}{c}46.6 \\
\mathrm{~W} / \mathrm{cm}^{2} \text { of foil }\end{array}$} \\
\hline $\begin{array}{c}\text { Minimum } \\
\text { Power in Plate }\end{array}$ & \multicolumn{4}{|c|}{$\begin{array}{c}7.9 \\
\mathrm{~W} / \mathrm{cm}^{2} \text { of foil }\end{array}$} & \multicolumn{4}{|c|}{$\begin{array}{c}8.9 \\
\mathrm{~W} / \mathrm{cm}^{2} \text { of foil }\end{array}$} \\
\hline
\end{tabular}


Table 3.5 gives the burnup state of the peak spot and peak stripe among the depleted cores which occurred for Core $189 \mathrm{BOC}$ and EOC, respectively.

In order to calculate ${ }^{235} \mathrm{U}$ fission density, the reference as-fabricated nominal density for ${ }^{235} \mathrm{U}$ is assumed to be $7.75 \times 10^{21}$ atoms $/ \mathrm{cm}^{3}[1]$. Since these results are for ${ }^{235} \mathrm{U}$ fissions, irradiation planning and results should state whether burnup is referenced in terms of ${ }^{235} \mathrm{U}$ fissions alone or also includes actinides.

Table 3.5. Axial burnup distribution of LEU cores with maximum heat flux locations.

\begin{tabular}{|c|c|c|c|}
\hline $\begin{array}{c}\text { Axial } \\
\text { Segment }\end{array}$ & $\begin{array}{c}\text { Axial Node Center } \\
\text { from Bottom of Fuel }\end{array}$ & $\begin{array}{c}\text { Core 189 BOC } \\
\text { Peak stripe }\end{array}$ & $\begin{array}{c}\text { Core 189 EOC } \\
\text { Peak stripe }\end{array}$ \\
\cline { 2 - 4 } (cm) & ${ }^{235}$ U Burnup \% & ${ }^{235}$ U Burnup \% \\
\hline 1 & 55.3 & 6.2 & 7.2 \\
\hline 2 & 52.1 & 6.2 & 7.2 \\
\hline 3 & 48.9 & 6.2 & 7.2 \\
\hline 4 & 45.8 & 8.3 & 10.9 \\
\hline 5 & 42.6 & 8.3 & 10.9 \\
\hline 6 & 39.5 & 8.3 & 10.9 \\
\hline 7 & 36.3 & 10.2 & 14.5 \\
\hline 8 & 33.2 & 10.2 & 14.5 \\
\hline 9 & 30.0 & 10.2 & 14.5 \\
\hline 10 & 26.8 & 10.6 & 15.6 \\
\hline 11 & 23.7 & 10.6 & 15.6 \\
\hline 12 & 20.5 & 10.6 & 15.6 \\
\hline 13 & 17.4 & 9.7 & 14.4 \\
\hline 14 & 14.2 & 9.7 & 14.4 \\
\hline 15 & 11.1 & 9.7 & 14.4 \\
\hline 16 & 7.9 & 8.5 & 12.9 \\
\hline 17 & 4.7 & 8.5 & 12.9 \\
\hline 18 & 1.6 & 8.5 & 12.9 \\
\hline
\end{tabular}




\subsubsection{Power Ramping during Fuel Lifetime}

Since the limiting power distributions occur in well-depleted elements, the fission rate in MITR elements with limiting power distributions will increase after the initial irradiation cycles. This phenomenon occurs when elements are moved from the inner rings of core loading to the outer ring since power peaking is much higher for the fuel immediately adjacent to the heavy water reflector. An increase of power peaking in depleted fuel is known to be a consideration for fuel failures, and limits have previously been quantified for existing fuel systems, such as aluminide fuels, in order to avoid fuel performance issues.

Any prior work in the fuel qualification of U10Mo fuel where power was increased later in the life of the fuel should be provided in order to corroborate that fuel performance is acceptable for power increases later in the life of the depleted MITR U10Mo elements. It would be beneficial to evaluate reproducing relevant phenomena in future experiments that precede MITR DDE irradiations.

Figure 3.4 shows the increase in power peaking later in the life of an MITR element. The figure plots the axial power distribution of the heat flux (q") for a $7 \mathrm{MW}$ core from a stripe of the fuel plate which is the most thermal hydraulically limiting of all MITR cores analyzed. This most limiting power distribution occurs for stripe 1 of element 27 plate 1 (adjacent to the reflector) in Core 189 EOC. The remainder of the cores in which this plate is loaded are shown at BOC and EOC in Figure 3.4 as the third axis. This element, MIT-335, is loaded for Cores 179-181 and 189-190, and has an approximately similar power during the cores where it resides in the interior of the core (B-ring during Cores 179-181). In the core interior, flux shape is flatter and hence a more uniform heat flux is generated in the plates of each element. After a period of storage, the element was loaded for Cores 189-190 into a C-ring location, at which point the peak power occurred for the plate adjacent to the reflector with the heat flux profile and burnup as listed in Tables 3.3-3.5.

The magnitude of the heat flux was highest of any depleted MITR core for this element at Core 189 BOC for the single location where power peaked in a spot with $76.6 \mathrm{~W} / \mathrm{cm}^{2}$ of foil as shown previously in Figure 3.2.

Whereas the plate distributions shown in Figure 3.2 remain important in order to represent the spatial rate of power change characteristic of MITR, Figure 3.4 illustrates increase in power over the course of the irradiation history with fuel movements. Stripe power increased by $63 \%$ and spot power by $43 \%$ when moved to the outer fuel ring, as listed in Table 3.6 despite being significantly depleted (see Table 3.5). Table 3.7 presents Core 179 power profiles for the plate which peaks later in lifetime during Core 189.

Table 3.6. Peak power plate when inserted as a fresh element and later in life at time of highest power.

\begin{tabular}{|c|c|c|c|}
\hline \multirow{2}{*}{$\begin{array}{c}\text { Peak Power Region } \\
\text { (element MIT-335) }\end{array}$} & \multicolumn{2}{|c|}{ Peak Power vs. Fuel Loading Position } & $\begin{array}{c}\text { Increase in Power } \\
\text { During Fuel Life } \\
\text { (peak outer/inner) }\end{array}$ \\
\cline { 2 - 3 } & Inner Fuel Ring & Outer Fuel Ring & $43 \%$ \\
\hline $\begin{array}{c}\text { Peak Location Power } \\
\left(\mathrm{W} / \mathrm{cm}^{2} \text {, single spot of foil) }\right.\end{array}$ & $\begin{array}{c}46.9 \\
\text { (Core 179 BOC) }\end{array}$ & $\begin{array}{c}76.6 \\
\text { (Core 189 BOC) }\end{array}$ & $\begin{array}{c}57.2 \\
\text { (Core 189 EOC) }\end{array}$ \\
\hline $\begin{array}{c}\text { Peak Stripe Power } \\
\left(\mathrm{W} / \mathrm{cm}^{2} \text { of foil, }\right. \\
\text { axially averaged) }\end{array}$ & $\begin{array}{c}39.9 \\
\text { (Core 179 BOC) }\end{array}$ & $63 \%$ \\
\hline
\end{tabular}




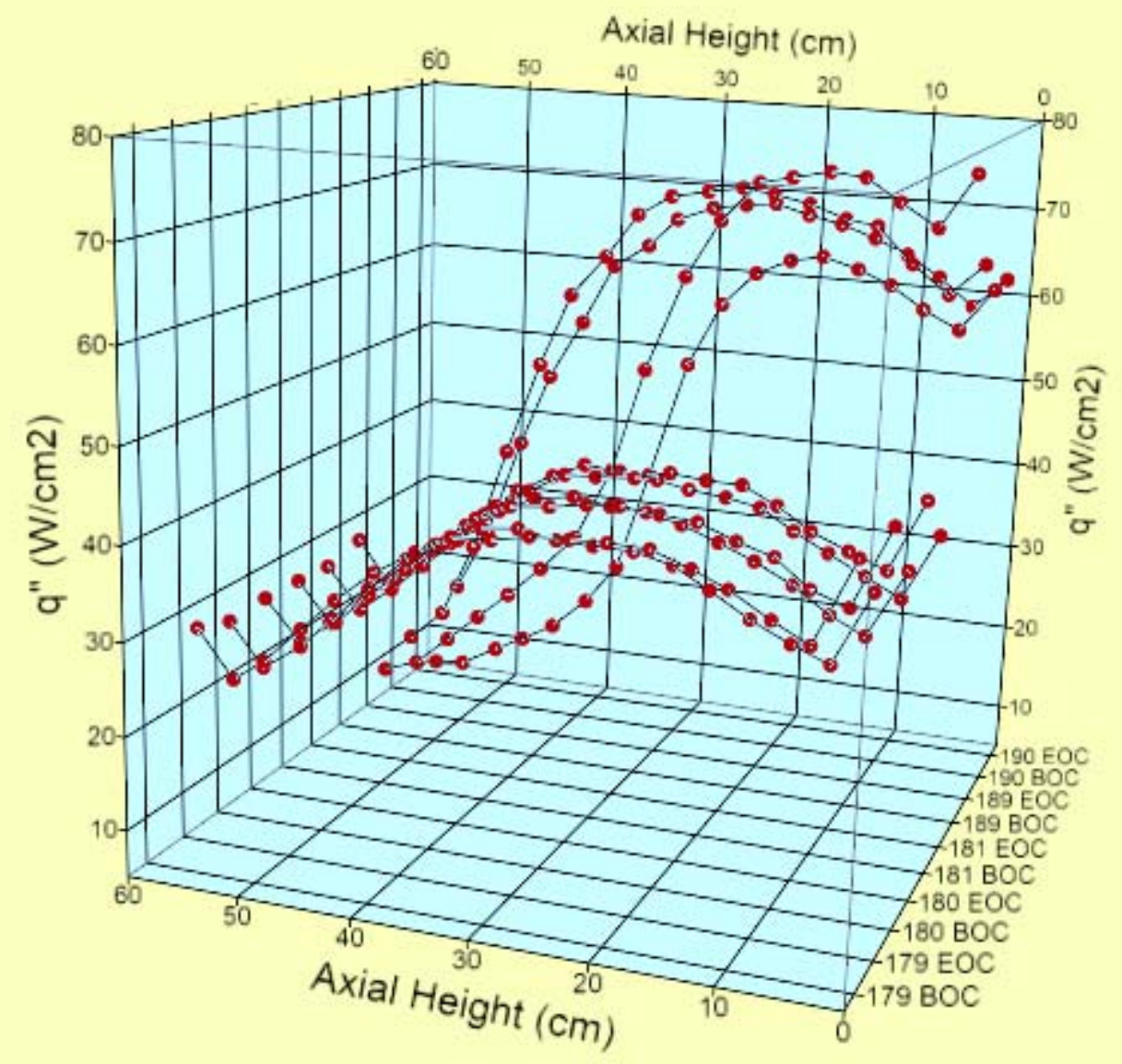

Figure 3.4. Axial heat flux (q") distribution for element of highest power: (MIT-335) during the fuel shuffling sequence of Cores 179-190. Peak heat flux occurs during Core 189 EOC in a well-depleted element due to movement adjacent to $\mathrm{D}_{2} \mathrm{O}$ reflector. Earlier cycles show that the nearly fresh element power is $>50 \%$ lower. Each curve shows q" vs. axial height from bottom of the fuel in the upflow MITR reactor. 
Table 3.7. Axial power distribution of element MIT-335 plate 1 when loaded into interior fuel ring position B1 during LEU Core 179.

\begin{tabular}{|c|c|c|c|c|c|c|c|c|}
\hline \multirow[b]{2}{*}{$\begin{array}{c}\text { Axial Node } \\
\text { Center from } \\
\text { Bottom of Fuel } \\
\text { (cm) }\end{array}$} & \multicolumn{8}{|c|}{ Heat Flux (W/cm of foil) } \\
\hline & \begin{tabular}{|c|} 
Core \\
179 \\
BOC \\
Stripe 1
\end{tabular} & \begin{tabular}{|c|} 
Core \\
179 \\
BOC \\
Stripe 2
\end{tabular} & \begin{tabular}{|c|} 
Core \\
179 \\
BOC \\
Stripe 3 \\
\end{tabular} & \begin{tabular}{|c|} 
Core \\
179 \\
BOC \\
Stripe 4
\end{tabular} & \begin{tabular}{|c|} 
Core \\
179 \\
EOC \\
Stripe 1 \\
\end{tabular} & \begin{tabular}{|c|} 
Core \\
179 \\
EOC \\
Stripe 2
\end{tabular} & \begin{tabular}{|c|} 
Core \\
179 \\
EOC \\
Stripe 3
\end{tabular} & \begin{tabular}{|l} 
Core \\
179 \\
EOC \\
Stripe 4
\end{tabular} \\
\hline $55.3^{a}$ & 31.1 & 21.8 & 20.0 & 21.6 & 29.8 & 21.4 & 19.6 & 21.1 \\
\hline 52.1 & 26.2 & 18.8 & 17.0 & 17.8 & 25.5 & 18.2 & 16.6 & 17.7 \\
\hline 48.9 & 29.0 & 21.8 & 20.1 & 20.8 & 28.2 & 21.3 & 19.7 & 20.8 \\
\hline 45.8 & 32.8 & 24.9 & 22.8 & 24.1 & 31.8 & 24.5 & 22.8 & 23.8 \\
\hline 42.6 & 36.5 & 28.0 & 25.8 & 26.9 & 35.5 & 27.6 & 25.5 & 27.1 \\
\hline 39.5 & 39.6 & 30.6 & 28.8 & 29.9 & 38.9 & 30.0 & 28.0 & 30.3 \\
\hline 36.3 & 41.9 & 32.9 & 30.9 & 31.8 & 41.1 & 32.3 & 30.3 & 32.2 \\
\hline 33.2 & 44.1 & 34.9 & 32.5 & 34.4 & 43.0 & 34.0 & 32.4 & 34.1 \\
\hline 30.0 & 44.2 & 36.1 & 34.1 & 35.9 & 43.6 & 34.9 & 33.7 & 36.2 \\
\hline 26.8 & 45.1 & 37.3 & 35.4 & 37.5 & 42.9 & 35.9 & 34.3 & 36.7 \\
\hline 23.7 & 45.2 & 37.6 & 36.3 & 38.6 & 42.8 & 35.6 & 34.5 & 36.9 \\
\hline 20.5 & 45.6 & 38.1 & 36.5 & 38.8 & 42.7 & 35.6 & 34.3 & 37.1 \\
\hline 17.4 & 45.2 & 37.8 & 36.3 & 38.5 & 41.7 & 35.0 & 33.5 & 35.9 \\
\hline 14.2 & 43.8 & 36.7 & 35.4 & 37.4 & 40.1 & 33.4 & 31.6 & 34.1 \\
\hline 11.1 & 42.6 & 34.3 & 33.4 & 35.4 & 37.5 & 31.0 & 30.1 & 32.4 \\
\hline 7.9 & 40.0 & 32.2 & 30.5 & 32.8 & 35.4 & 28.6 & 27.0 & 29.3 \\
\hline 4.7 & 38.4 & 29.0 & 27.0 & 30.1 & 34.0 & 25.4 & 23.8 & 26.6 \\
\hline $1.6^{\mathrm{b}}$ & 46.9 & 35.6 & 34.0 & 38.2 & 41.8 & 31.2 & 29.8 & 33.4 \\
\hline Stripe Average & 39.9 & 31.6 & 29.8 & 31.7 & 37.6 & 29.8 & 28.2 & 30.3 \\
\hline
\end{tabular}

${ }^{a}$ Top of LEU fuel foil in upflow reactor is at $223 / 8$ inch $(56.8325 \mathrm{~cm})$.

${ }^{\mathrm{b}}$ Bottom of LEU fuel foil in upflow reactor is at zero.

\subsubsection{Fuel Plate Lateral Power Peaking}

The plate with the maximum fission density and heat flux was presented previously where the lateral discretization of the plate, transverse to the flow direction, was determined based upon the thermal hydraulic requirements. The discretization of the fuel into four $1.32 \mathrm{~cm}$ lateral stripes represented the heat flux into the coolant channel without overestimating the effect of lateral power peaking on the sides of the plate [4].

In this report, fuel irradiation parameters are also of interest, and so a calculation of a more detailed power distribution was performed for the plate found to have the highest local heat flux based upon the analyses performed to establish thermal hydraulic margin. This plate heat flux distribution previously shown in Table 3.3 has been further subdivided laterally into sixteen stripes as shown in Table 3.8. Figure 3.5 illustrates power peaking on the sides of the plate for various lateral divisions where the bottom axial node corresponding to the peak power location is shown. 
Table 3.8. Detailed lateral axial heat flux distribution in plate with maximum power location.

\begin{tabular}{|c|c|c|c|c|c|c|c|c|c|c|c|c|c|c|c|c|}
\hline & \multicolumn{16}{|c|}{ Heat Flux (W/ $\mathrm{cm}^{2}$ of foil) at $7 \mathrm{MW}$} \\
\hline & $\begin{array}{c}\text { Stripe } \\
1 \\
\end{array}$ & $\begin{array}{c}\text { Stripe } \\
2 \\
\end{array}$ & $\begin{array}{c}\text { Stripe } \\
3 \\
\end{array}$ & $\begin{array}{c}\text { Stripe } \\
4 \\
\end{array}$ & $\begin{array}{c}\text { Stripe } \\
5\end{array}$ & $\begin{array}{c}\text { Stripe } \\
6 \\
\end{array}$ & $\begin{array}{c}\text { Stripe } \\
7 \\
\end{array}$ & $\begin{array}{c}\text { Stripe } \\
8 \\
\end{array}$ & $\begin{array}{c}\text { Stripe } \\
9 \\
\end{array}$ & $\begin{array}{c}\text { Stripe } \\
10 \\
\end{array}$ & $\begin{array}{c}\text { Stripe } \\
11 \\
\end{array}$ & $\begin{array}{c}\text { Stripe } \\
12 \\
\end{array}$ & $\begin{array}{c}\text { Stripe } \\
13 \\
\end{array}$ & $\begin{array}{c}\text { Stripe } \\
14 \\
\end{array}$ & $\begin{array}{c}\text { Stripe } \\
15\end{array}$ & $\begin{array}{c}\text { Stripe } \\
16 \\
\end{array}$ \\
\hline $\begin{array}{l}\text { Axial Node } \\
\text { Center } \\
\text { from } \\
\text { Bottom of } \\
\text { Fuel }(\mathrm{cm}) \\
\end{array}$ & $\begin{array}{l}0.00 \text { to } \\
0.33 \mathrm{~cm}\end{array}$ & $\begin{array}{l}0.33 \text { to } \\
0.66 \mathrm{~cm}\end{array}$ & $\begin{array}{l}0.66 \text { to } \\
0.99 \mathrm{~cm}\end{array}$ & $\begin{array}{l}0.99 \text { to } \\
1.32 \mathrm{~cm}\end{array}$ & $\begin{array}{l}1.32 \text { to } \\
1.65 \mathrm{~cm}\end{array}$ & $\begin{array}{l}1.65 \text { to } \\
1.98 \mathrm{~cm}\end{array}$ & $\begin{array}{l}1.98 \text { to } \\
2.31 \mathrm{~cm}\end{array}$ & $\begin{array}{l}2.31 \text { to } \\
2.64 \mathrm{~cm}\end{array}$ & $\begin{array}{l}2.64 \text { to } \\
2.97 \mathrm{~cm}\end{array}$ & $\begin{array}{l}2.97 \text { to } \\
3.31 \mathrm{~cm}\end{array}$ & $\begin{array}{l}3.31 \text { to } \\
3.64 \mathrm{~cm}\end{array}$ & $\begin{array}{l}3.64 \text { to } \\
3.97 \mathrm{~cm}\end{array}$ & $\begin{array}{l}3.97 \text { to } \\
4.30 \mathrm{~cm}\end{array}$ & $\begin{array}{l}4.30 \text { to } \\
4.63 \mathrm{~cm}\end{array}$ & $\begin{array}{l}4.63 \text { to } \\
4.96 \mathrm{~cm}\end{array}$ & $\begin{array}{l}4.96 \text { to } \\
5.29 \mathrm{~cm}\end{array}$ \\
\hline 55.3 & 15.1 & 13.1 & 11.7 & 10.4 & 9.7 & 9.4 & 8.7 & 8.0 & 7.8 & 7.8 & 8.0 & 7.5 & 7.3 & 7.4 & 7.8 & 8.2 \\
\hline 52.1 & 16.7 & 14.7 & 12.7 & 11.8 & 10.8 & 9.9 & 9.5 & 8.9 & 8.7 & 8.3 & 8.1 & 8.0 & 7.6 & 8.0 & 7.9 & 8.4 \\
\hline 48.9 & 21.4 & 18.2 & 16.5 & 14.5 & 13.7 & 12.6 & 11.3 & 10.7 & 10.5 & 10.0 & 9.8 & 9.5 & 9.6 & 9.4 & 9.4 & 9.9 \\
\hline 45.8 & 26.0 & 22.0 & 19.3 & 17.9 & 15.4 & 14.6 & 13.6 & 13.2 & 12.5 & 11.4 & 11.6 & 11.1 & 11.0 & 10.9 & 11.0 & 11.2 \\
\hline 42.6 & 30.7 & 25.4 & 22.6 & 20.0 & 18.2 & 17.1 & 15.5 & 15.1 & 13.9 & 13.5 & 13.3 & 12.9 & 12.6 & 12.7 & 12.5 & 13.4 \\
\hline 39.5 & 34.3 & 28.7 & 25.8 & 23.2 & 21.1 & 18.9 & 18.0 & 16.8 & 16.1 & 15.5 & 14.9 & 14.7 & 14.5 & 14.4 & 14.4 & 15.3 \\
\hline 36.3 & 40.0 & 33.2 & 29.0 & 26.3 & 24.0 & 22.1 & 20.6 & 19.8 & 18.5 & 17.9 & 16.9 & 16.2 & 16.2 & 15.9 & 15.8 & 17.1 \\
\hline 33.2 & 48.1 & $\begin{array}{l}41.4 \\
\end{array}$ & 36.2 & 32.3 & 29.9 & 28.4 & 26.3 & 24.8 & 23.0 & 21.7 & 20.9 & 20.0 & 19.7 & 19.2 & 19.7 & 20.6 \\
\hline 30 & 60.8 & 54.2 & 48.7 & 45.1 & 43.0 & 40.3 & 38.1 & 36.0 & 35.0 & 32.8 & 31.6 & 30.4 & 28.9 & 28.3 & 28.3 & 29.4 \\
\hline 26.8 & 71.0 & 63.7 & 59.3 & 57.1 & 54.5 & 54.2 & 53.4 & 52.1 & 50.6 & 49.9 & 48.4 & 47.8 & 47.4 & 46.8 & 47.0 & 49.9 \\
\hline 23.7 & 78.5 & 71.1 & 66.1 & 64.2 & 62.5 & $\begin{array}{l}61.4 \\
\end{array}$ & 60.5 & 59.7 & 59.0 & 59.6 & 58.9 & 58.9 & $\begin{array}{l}60.1 \\
\end{array}$ & 60.1 & 62.0 & 65.8 \\
\hline 20.5 & 82.2 & 74.5 & 70.3 & 67.4 & 66.4 & 65.2 & 63.9 & 63.5 & 63.9 & 63.3 & 64.1 & 63.5 & 64.1 & 65.4 & 66.4 & 72.1 \\
\hline 17.4 & 83.9 & 75.4 & 72.2 & 69.8 & 67.8 & 66.1 & 65.2 & 65.5 & 65.0 & 63.0 & 64.6 & 64.5 & 65.5 & 66.0 & 68.7 & 74.0 \\
\hline 14.2 & 84.6 & 76.2 & 70.8 & 68.4 & 67.0 & 65.5 & 66.0 & 64.4 & 64.1 & 64.2 & 63.3 & 64.8 & 65.2 & 65.6 & 67.7 & 74.2 \\
\hline 11.1 & 86.7 & 76.2 & 71.2 & 68.5 & 65.7 & 63.9 & 62.7 & 63.4 & 62.9 & 61.8 & 62.1 & 62.7 & 63.1 & 64.0 & 65.4 & 71.4 \\
\hline 7.9 & 84.6 & 74.0 & 68.9 & 65.9 & 64.0 & 61.5 & 62.2 & 60.9 & 59.4 & 60.1 & 59.7 & 60.4 & 60.8 & 60.7 & 62.9 & 68.7 \\
\hline 4.7 & 82.9 & 71.1 & 65.9 & 63.2 & 61.3 & 60.0 & 59.7 & 58.4 & 57.9 & 57.4 & 57.5 & 58.2 & 58.0 & 58.8 & 60.0 & 66.0 \\
\hline 1.6 & 86.8 & 76.9 & 70.8 & 68.4 & 66.2 & 65.4 & 64.6 & 63.4 & 64.1 & 63.0 & 63.9 & 64.3 & 63.3 & 64.8 & 66.7 & 72.4 \\
\hline $\begin{array}{c}\text { Stripe } \\
\text { Average }\end{array}$ & 57.5 & 50.5 & 46.6 & 44.1 & 42.3 & 40.9 & 40.0 & 39.2 & 38.5 & 37.8 & 37.6 & 37.5 & 37.5 & 37.7 & 38.5 & 41.5 \\
\hline
\end{tabular}




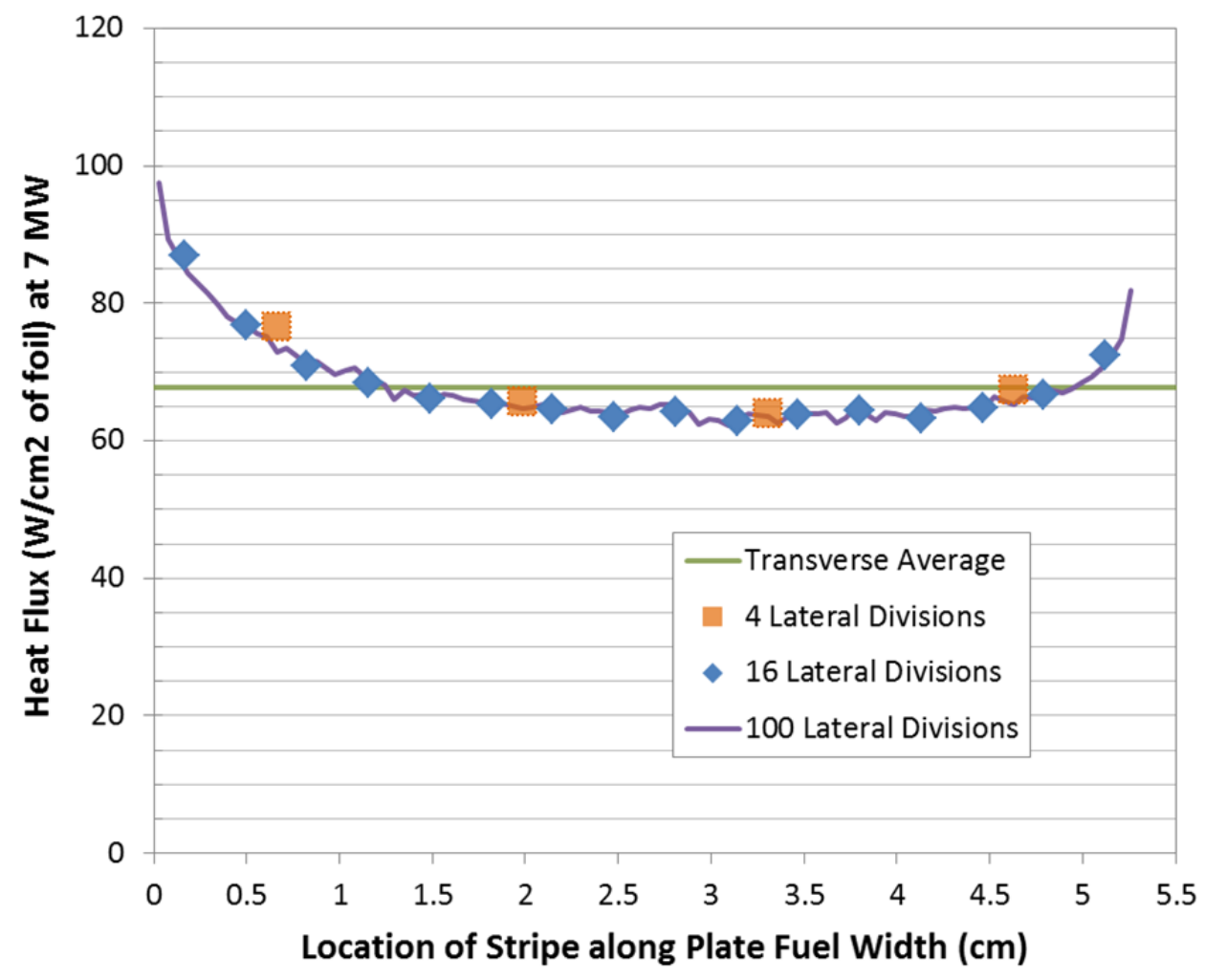

Figure 3.5. Maximum local power distribution shown with detailed divisions along the plate fuel width, shown for the bottom axial region.

Heat flux profile along the width of the plate is shown for cases with 1, 4, 16, and 100 divisions laterally. Each of these nodes maintained a $<1 \% 1$-sigma relative error in the MCNP power calculation. Table 3.9 summarizes the heat flux in the edge node, where the values are tabulated for the bottom axial node with maximum power. As expected power increases as the size of the transverse node discretization is made smaller, up to nearly $100 \mathrm{~W} / \mathrm{cm}^{2}$. It is also seen that if 16 divisions were extrapolated to the edge a similar value is obtained $\left(\sim 95 \mathrm{~W} / \mathrm{cm}^{2}\right)$. For all these cases the surface heat flux, which is relevant to thermal hydraulic analysis, is anticipated to be no higher than the 4-stripe case due to the effect of lateral heat conduction into the sides of the plates. As seen in Table 3.1, these results conservatively neglect the significant reduction in power peaking which would be expected if lateral depletion regions were included $[5,21]$. This data is shown to provide a basis for comparing fission rate density since spatial power discretization varies among the U.S. high performance reactors for which monolithic fuel is being developed.

Table 3.9. Effect of lateral division of heat flux distribution in plate with maximum power location.

\begin{tabular}{|c|c|c|c|c|}
\hline $\begin{array}{c}\text { Lateral } \\
\text { Division of } \\
\text { Fuel Plate }\end{array}$ & $\begin{array}{l}\text { Lateral } \\
\text { Stripe Size } \\
\text { (cm) }\end{array}$ & $\begin{array}{c}\text { Heat Flux in } \\
\left(\mathrm{W} / \mathrm{cm}^{2}\right) \\
\text { at } 7 \mathrm{MW}\end{array}$ & $\begin{array}{l}\text { Fission Rate } \\
\text { Density } \\
\left(10^{14} \mathrm{~cm}^{-3} \mathrm{~s}^{-1}\right)\end{array}$ & $\begin{array}{c}\text { Change vs. } \\
\text { Lateral } \\
\text { Average }\end{array}$ \\
\hline average & 5.29 & 67.8 & 0.8 & $0 \%$ \\
\hline 4-stripe & 1.32 & 76.6 & 0.9 & $13 \%$ \\
\hline 16-stripe & 0.33 & 86.8 & 1.1 & $28 \%$ \\
\hline 100-stripe & 0.05 & 97.5 & 1.2 & $44 \%$ \\
\hline
\end{tabular}




\subsection{Fuel Burnup and Fission Density}

The MITR has flexible fuel management, and a variable core configuration with interchangeable fuel and non-fuel element locations. MITR is also capable of operating with different numbers of fuel elements (typically 22 to 25), in-core experimental assemblies, and non-fuel elements. For these reasons, and due to element flipping, rotation, storage of elements, and a range of experiment-based irradiation cycle times, the reactor has not had a closed equilibrium fuel cycle. Instead, each core is assembled from elements which have operated in and out of storage over the course of several years. In this section the distribution of fuel burnup has been analyzed from the series of cores representative of historical MITR operation. As listed in Table 3.1 each plate has six independently depleting materials regions each one-sixth of the axial length of the fuel zone. For safety analysis the depletion regions provide a conservative power distribution. However, in order to estimate the local transverse peaking of the burnup, a transverse power peaking factors has been applied to the burnup of each 18 axial power distribution zones. While the average remains unchanged, maximum local burnup is increased. This method of burnup calculation has not been required in safety analyses and overestimates the burnup achieved to some degree unless lateral depletion of materials is modeled. Given the versatile fuel cycle, this conservative estimation of burnup is appropriate to identify the expected operating range of MITR.

Figures 3.6 and 3.7 provide the axial ${ }^{235} \mathrm{U}$ burnup profile for the plates with the locations of highest and second-highest burnup. These occurred in Core 189 BOC element 17 plate 1 stripe 1, and Core 185 EOC element 22 plate 1 stripe 4, respectively. Figure 3.7 is seen to have a more pronounced shape, and besides the lower control blade position at BOC, this element is seen to have flipped due to the location of the burnup peak. The fuel management simulation performed provided axial shape for each plate based on 6 axial depletion zones in each plate $(9.47 \mathrm{~cm}$ zones). The fuel was not subdivided in the lateral direction for depletion due to the large number of depletion zones that would have created. Table 3.10 shows the lateral power peaking factor from the MCNP power distribution analysis applied to obtain an estimate of peak local burnup values. Based on these estimates, the calculated LEU fuel peak local ${ }^{235} \mathrm{U}$ fission density is $5.2 \times 10^{21} \mathrm{~cm}^{-3}$ corresponding to a burnup of $67 \%$.

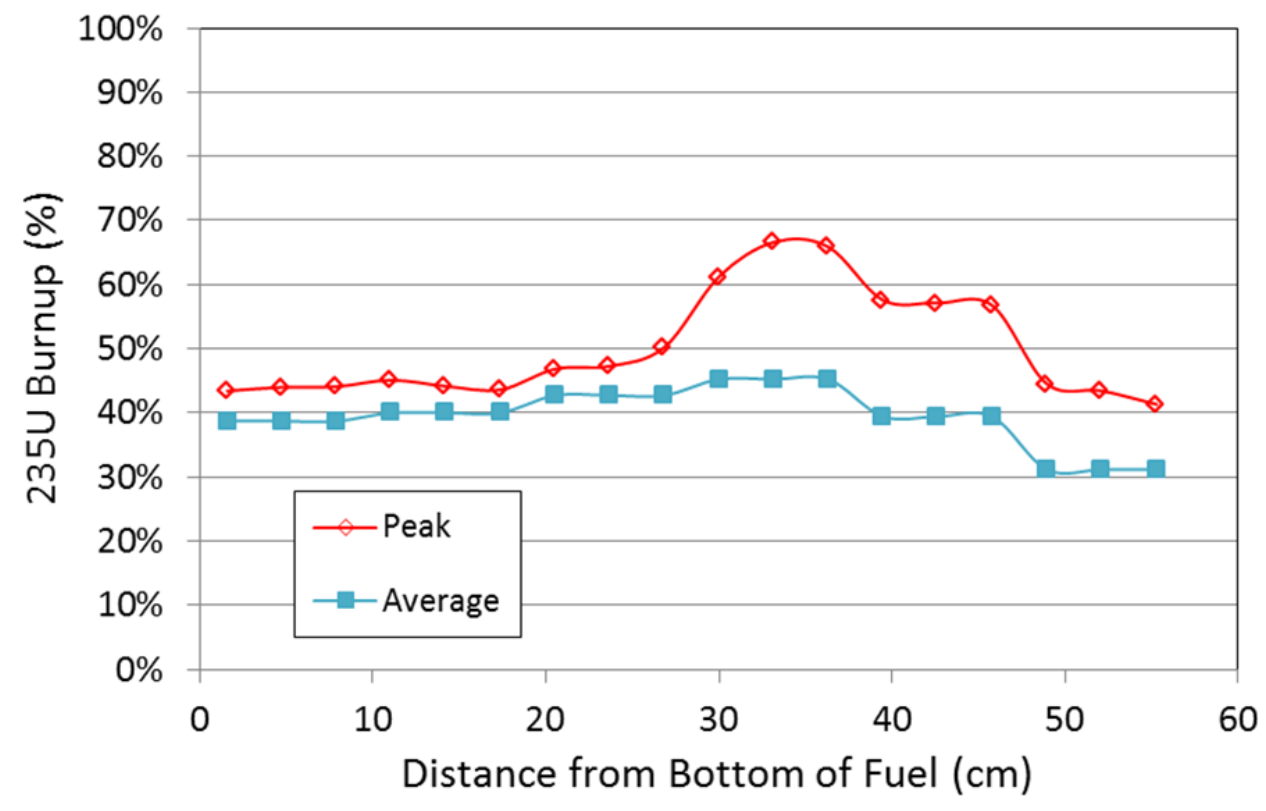

Figure 3.6. Average and peak stripe axial burnup profile for plate with highest fission density. 


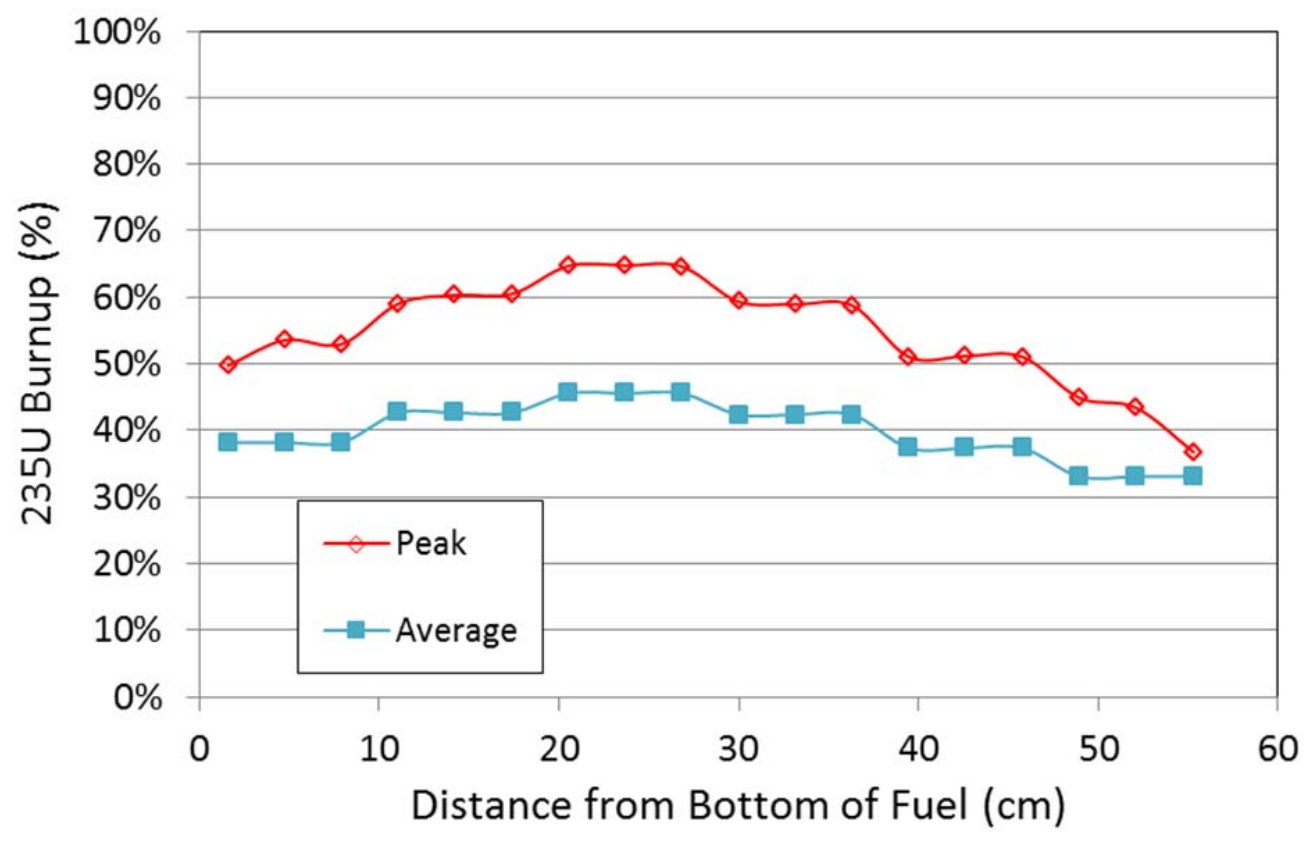

Figure 3.7. Plate average and peak stripe axial burnup profile for plate with second highest fission density.

Table 3.10. Maximum ${ }^{235} \mathrm{U}$ burnup in LEU Fuel Plates.

\begin{tabular}{|c|c|c|c|c|c|c|}
\hline \multirow{2}{*}{$\begin{array}{c}\text { Distance from Bottom } \\
\text { of Fuel (cm) }\end{array}$} & \multicolumn{3}{|c|}{ Core 185 EOC } & \multicolumn{3}{c|}{ Core 189 BOC } \\
\cline { 2 - 6 } & $\begin{array}{c}\text { Average } \\
\text { 235 U } \\
\text { Burnup }\end{array}$ & $\begin{array}{c}\text { Lateral } \\
\text { Peaking } \\
\text { Factor }\end{array}$ & $\begin{array}{c}\text { Peak } \\
{ }^{235} \mathbf{U} \\
\text { Burnup }\end{array}$ & $\begin{array}{c}\text { Average } \\
{ }^{235} \mathbf{U} \\
\text { Burnup }\end{array}$ & $\begin{array}{c}\text { Lateral } \\
\text { Peaking } \\
\text { Factor }\end{array}$ & $\begin{array}{c}\text { Peak } \\
\text { Burnup U }\end{array}$ \\
\hline 55.3 & $33 \%$ & 1.11 & $37 \%$ & $31 \%$ & 1.33 & $41 \%$ \\
\hline 52.1 & $33 \%$ & 1.31 & $43 \%$ & $31 \%$ & 1.39 & $43 \%$ \\
\hline 48.9 & $33 \%$ & 1.36 & $45 \%$ & $31 \%$ & 1.43 & $45 \%$ \\
\hline 45.8 & $37 \%$ & 1.37 & $51 \%$ & $39 \%$ & 1.44 & $57 \%$ \\
\hline 42.6 & $37 \%$ & 1.37 & $51 \%$ & $39 \%$ & 1.45 & $57 \%$ \\
\hline 39.5 & $37 \%$ & 1.37 & $51 \%$ & $39 \%$ & 1.46 & $58 \%$ \\
\hline 36.3 & $42 \%$ & 1.39 & $59 \%$ & $45 \%$ & 1.46 & $66 \%$ \\
\hline 33.2 & $42 \%$ & 1.39 & $59 \%$ & $45 \%$ & 1.47 & $\mathbf{6 7 \%}$ \\
\hline 30.0 & $42 \%$ & 1.40 & $59 \%$ & $45 \%$ & 1.35 & $61 \%$ \\
\hline 26.8 & $46 \%$ & 1.42 & $65 \%$ & $43 \%$ & 1.18 & $50 \%$ \\
\hline 23.7 & $46 \%$ & 1.42 & $65 \%$ & $43 \%$ & 1.11 & $47 \%$ \\
\hline 20.5 & $46 \%$ & 1.42 & $65 \%$ & $43 \%$ & 1.10 & $47 \%$ \\
\hline 17.4 & $43 \%$ & 1.42 & $61 \%$ & $40 \%$ & 1.09 & $44 \%$ \\
\hline 14.2 & $43 \%$ & 1.41 & $60 \%$ & $40 \%$ & 1.10 & $44 \%$ \\
\hline 11.1 & $43 \%$ & 1.38 & $59 \%$ & $40 \%$ & 1.13 & $45 \%$ \\
\hline 7.9 & $38 \%$ & 1.39 & $53 \%$ & $39 \%$ & 1.14 & $44 \%$ \\
\hline 4.7 & $38 \%$ & 1.40 & $54 \%$ & $39 \%$ & 1.14 & $44 \%$ \\
\hline 1.6 & $38 \%$ & 1.30 & $50 \%$ & $39 \%$ & 1.12 & $43 \%$ \\
\hline
\end{tabular}




\subsection{Maximum Steady-State Temperatures for LEU Fuel}

Modeling has performed in order to determine steady state temperatures in the nominal power $7 \mathrm{MW}$ MITR core [10]. Figure 3.8 shows the fuel and cladding axial temperature profile corresponding to nominal conditions for the core with the peak stripe (Core 189 EOC element 27 plate 1 stripe 1). At the location of peak temperature in the nominal $7 \mathrm{MW}$ LEU core, the model yields a peak LEU fuel temperature of less than $100^{\circ} \mathrm{C}$, and peak surface temperature in the cladding of $90^{\circ} \mathrm{C}$.

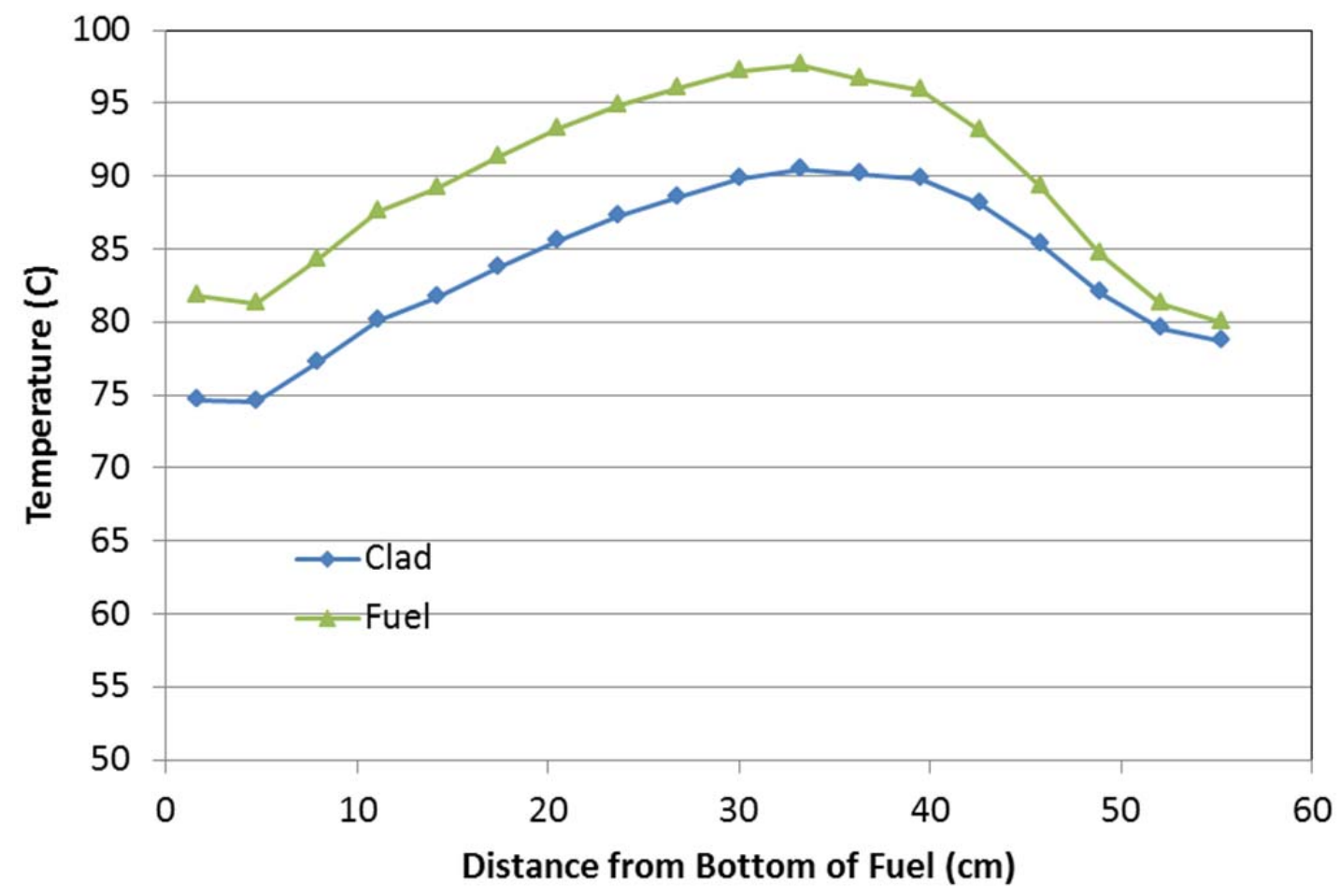

Figure 3.8. Axial temperature profile of peak stripe. 


\subsection{LEU IRRADIATION PARAMETERS WITH UNCERTAINTIES}

Maximum local parameters calculated for steady-state LEU cores in the most limiting configurations were presented in Section 3 without uncertainties. Safety analyses have accounted for uncertainties including tolerances in geometry and materials as described in Table 2.2-2.4. Table 4.1 summarizes the data from Section 3 along with applicable hot channel factors (HCFs) based upon data in Table 2.4 and other uncertainty assumptions made in the safety analyses. The table lists total HCFs, which combine individual HCF components statistically using the method employed in the HEU safety analyses [21]. Other LEU analyses currently represent the distributions modeled with Monte Carlo sampling. Heat flux and fission rate are readily calculated without Monte Carlo sampling and so Table 4.1 uses the total uncertainty to estimate conditions at both the maximum licensed and LSSS power levels.

Table 4.1. Maximum parameters and uncertainties assumed for LEU fuel irradiation experiments.

\begin{tabular}{|c|c|c|c|}
\hline Core Condition & $\begin{array}{c}\text { Fission Rate } \\
\text { Density }\end{array}$ & $\begin{array}{l}{ }^{235} \text { U Fission } \\
\text { Density }\end{array}$ & Heat Flux \\
\hline $\begin{array}{l}\text { Maximum Licensed Power } \\
\text { without HCFs ( } 7 \mathrm{MW})\end{array}$ & $1.2 \times 10^{14} \mathrm{~cm}^{-3} \mathrm{~s}^{-1}$ & $5.2 \times 10^{21} \mathrm{~cm}^{-3}$ & $97.5 \mathrm{~W} / \mathrm{cm}^{2}$ \\
\hline \multicolumn{4}{|l|}{ Hot Channel Factors } \\
\hline $\begin{array}{l}\text { Fuel Meat Thickness \& } \\
{ }^{235} \text { U Homogeneity (Local)* }\end{array}$ & - & - & 1.05 \\
\hline Calculated Power Distribution & 1.10 & - & 1.10 \\
\hline Power Measurement & 1.05 & - & 1.05 \\
\hline Total & 1.1 & $1.20^{+}$ & 1.12 \\
\hline $\begin{array}{l}\text { Maximum Licensed Power } \\
\text { with HCFs ( } 7 \text { MW) }\end{array}$ & $1.3 \times 10^{14} \mathrm{~cm}^{-3} \mathrm{~s}^{-1}$ & \multirow{2}{*}{$6.2 \times 10^{21} \mathrm{~cm}^{-3}$} & $109 \mathrm{~W} / \mathrm{cm}^{2}$ \\
\hline LSSS Power (8.4 MW) with HCFs & $1.6 \times 10^{14} \mathrm{~cm}^{-3} \mathrm{~s}^{-1}$ & & $131 \mathrm{~W} / \mathrm{cm}^{2}$ \\
\hline
\end{tabular}

Safety analyses have applied HCFs to heat flux for combined fuel thickness and local ${ }^{235} \mathrm{U}$ homogeneity, and uncertainties in calculated power distribution. For LEU Monte Carlo sampling, these factors have been combined with calculated power distribution. Overall reactor power was sampled separately based on measurement uncertainty.

Since clad surface heat flux was used to determine thermal hydraulic margin in the reactor, safety analyses have not required direct calculation of the fission rate, and associated HCFs. For fission rate, the power distribution calculation uncertainty was assumed to be the same as for heat flux. However, for fission rate density the combined thickness and homogeneity HCF would be dominated by the homogeneity of the fuel rather than the tolerance on thickness. Homogeneity uncertainty is estimated to be significantly less than other applicable HCFs, and so this HCF component is neglected for fission rate.

An uncertainty of $20 \%$ has been assigned to the fission density, which accounts primarily for adjustments in fuel management. Temperature uncertainties are not listed in this table since these were not currently a focus of the irradiation experiment design in a test reactor. 


\subsection{SUMMARY}

The preceding sections provide plate performance data for a number of core states that would exist during steady-state operations of the MITR [4]. The plates presented were selected from LEU elements under the conditions that are expected in steady-state operations to yield the highest plate heat flux, fuel and cladding temperatures, fission rate density, and cumulative fission density. It should be noted that this data represents, within the local plate shapes specific to MITR, peak local performance parameters expected for the LEU core based on nominal steady-state conditions without engineering hot channel uncertainty factors. Manufacturing tolerances and other uncertainties in reactor geometry and materials are also presented and used to estimate the steady-state upper bound of key irradiation parameters with uncertainties. As a part of the experiment design, uncertainties in the irradiation experiment in the test reactors should be considered to ensure that conditions are adequately met.

As discussed in this report, the design and safety analysis of the proposed MITR LEU element has been performed within the context of an ongoing and larger campaign to qualify U10Mo fuel for use in various reactors. While the set of irradiation parameters presented here provide data on select plates of interest to fuel irradiation experiments, it should be noted that further data may be useful among the wide variety of individual plate irradiation conditions that would be present in MITR LEU cores. Thus, further cooperative work should continue between MITR and the RC, FD and FFC pillars to ensure that appropriate data is available to plan irradiations which include peak conditions, as well as within plate distributions and any other parameters found relevant to fuel performance. 


\section{REFERENCES}

[1] T.H. Newton, Jr., "Development of a Low Enrichment Uranium Core for the MIT Reactor," Massachusetts Institute of Technology dissertation, Cambridge, Massachusetts, 2006.

[2] E.H. Wilson, T.H. Newton, Jr., A. Bergeron, N. Horelik, and J.G. Stevens, "Comparison and Validation of HEU and LEU Modeling Results to HEU Experimental Benchmark Data for the Massachusetts Institute of Technology MITR Reactor," ANL-RERTR-TM-10-41, Argonne National Laboratory, December, 2010.

[3] T.H. Newton, Jr., E.H. Wilson, A. Bergeron, N. Horelik, and J.G. Stevens, "Neutronic Analyses for HEU to LEU Fuel Conversion of the Massachusetts Institute of Technology MITR Reactor," ANLRERTR-TM-10-40, Argonne National Laboratory December 2010.

[4] E.H. Wilson, N. Horelik, F.E. Dunn, T.H. Newton, Jr., L. Hu, and J.G. Stevens, "Power distributions in Fresh and Depleted LEU and HEU Cores of the MITR Reactor," ANL-RERTRTM-12-3 Revision 0, Argonne National Laboratory, February, 2012.

[5] N.E. Horelik, "Expanding and Optimizing Fuel Management and Data Analysis Capabilities of MOCDE-FM in Support of MIT Research Reactor (MITR-II) LEU Conversion," Massachusetts Institute of Technology dissertation, Cambridge, Massachusetts, 2012.

[6] E.H. Wilson, N.E. Horelik, A. Bergeron, T.H. Newton, Jr., F. Dunn, L. Hu, J.G. Stevens, "Neutronic Modeling of the MIT Reactor LEU Conversion," Trans. Am. Nuclear Soc. 106, 1, 849852 (2012).

[7] E. Wilson, T. Newton, Jr., N. Horelik, T. Gerrity, H. Connaway, and B. Forget, "Neutronic Analysis Capabilities for Conversion of the MIT Reactor to LEU Fuel," Proceedings of the RERTR Conference, Warsaw, Poland, October, 2012.

[8] L. Hu, T.H. Newton, E.H. Wilson, J.G. Stevens, "Preliminary Safety Analysis Report Methodologies and Scenarios for LEU Fuel Conversion of the MITR Reactor," MITNRL-11-01, MIT Nuclear Reactor Laboratory, Massachusetts Institute of Technology, Cambridge, Massachusetts, April, 2011.

[9] L. Hu, K. Chiang, E.H. Wilson, F.E. Dunn, T.H. Newton, Jr., and J.G. Stevens, “Thermal Hydraulic Limits Analysis for LEU Fuel Conversion of the MIT Reactor," MITNRL-12-01, Massachusetts Institute of Technology, March 2012.

[10] F. E. Dunn, L. Hu, K. Chiang, E. Wilson, T. H. Newton, Jr., and J.G. Stevens, "Calculations of LSSS Limits for Use of LEU Fuel in the MITR-II Reactor," Conf. of Am. Nucl. Soc., San Diego, California, November, 2012.

[11] E.H. Wilson, T.H. Newton, Jr., F. Dunn, L. Hu, J.G. Stevens, "Conceptual Design Parameters for MITR LEU U-Mo Fuel Conversion Demonstration Experimental Irradiations," ANL-RERTR-TM12-28, Argonne National Laboratory June 2012.

[12] MITR-II "Fuel Element Assembly," drawing R3F-201-4, MIT Nuclear Reactor Laboratory, Massachusetts Institute of Technology, Cambridge, Massachusetts. 
[13] "Specification for Massachusetts Institute of Technology Fuel Elements," TRTR-3 Revision 1, EG\&G Idaho, Inc., June, 1985.

[14] "The Y-12 Standard Specification Low Enriched Uranium Metal Supply to Research and Test Reactors," Y/GNSS/05-05 Revision 2, Y-12 National Security Complex, August 2007.

[15] E.H. Wilson and F.E. Dunn, T.H. Newton, Jr. and L. Hu, "Safety Analysis of the MIT Nuclear Reactor for Conversion to LEU Fuel," Fifth International Symposium on Material Testing Reactors, Columbia, Missouri, October, 2012.

[16] E.H. Wilson, T.H. Newton, Jr., F. Dunn, L. Hu, J.G. Stevens, "Conceptual Design Parameters for MITR LEU U-Mo Fuel Conversion Demonstration Experimental Irradiations," ANL-RERTR-TM12-28, Argonne National Laboratory June 2012.

[17] Z. Xu, P. Hejzlar, and M.S. Kazimi, "MCODE, Version 2.2 - An MCNP-ORIGEN Depletion Program," Center for Advanced Nuclear Systems, Massachusetts Institute of Technology, Cambridge, Massachusetts, April 2006.

[18] A.G. Croff, "A User's Manual for the ORIGEN2 Computer Code," ORNL/TM-7175, Oak Ridge National Laboratory (1980).

[19] "MCNP - A General Monte Carlo N-Particle Transport Code, Version 5 User's Guide Manual," X-5 Monte Carlo Team, LA-UR-03-1987, Los Alamos National Laboratory, April, 2003.

[20] E. Wilson, T. Newton, Jr., N. Horelik, T. Gerrity, H. Connaway, and B. Forget, "Neutronic Analysis Capabilities for Conversion of the MIT Reactor to LEU Fuel," Proceedings of the RERTR Conference, Warsaw, Poland, October, 2012.

[21] "Safety Analysis Report for the MIT Research Reactor," MITNRL-11-02, MIT Nuclear Reactor Laboratory, Massachusetts Institute of Technology, Cambridge, Massachusetts, August 2011. 

Argonne

Nuclear Engineering Division

Argonne National Laboratory

9700 South Cass Avenue, Bldg. 208

Argonne, IL 60439

wWw.anl.gov 